\title{
Effects of Soil Moisture on the Responses of Soil Temperatures to Climate Change in Cold Regions*
}

\author{
ZACHARY M. SUBIN \\ Princeton Environmental Institute, Princeton, New Jersey, and Lawrence Berkeley National Laboratory, Berkeley, California \\ Charles D. Koven, William J. Riley, and Margaret S. Torn \\ Lawrence Berkeley National Laboratory, Berkeley, California \\ DAVID M. LAWRENCE AND SEAN C. SWENSON \\ National Center for Atmospheric Research, Boulder, Colorado
}

(Manuscript received 31 May 2012, in final form 26 September 2012)

\begin{abstract}
At high latitudes, changes in soil moisture could alter soil temperatures independently of air temperature changes by interacting with the snow thermal rectifier. The authors investigated this mechanism with model experiments in the Community Land Model 4 (CLM4) with prescribed atmospheric forcing and vegetation state. Under equilibrium historical conditions, increasing $\mathrm{CO}_{2}$ concentrations experienced by plants from 285 to $857 \mathrm{ppm}$ caused local increases in soil water-filled pore space of $0.1-0.2$ in some regions throughout the globe. In permafrost regions that experienced this moistening, vertical- and annual- mean soil temperatures increased by up to $3^{\circ} \mathrm{C}\left(0.27^{\circ} \mathrm{C}\right.$ averaged over all permafrost areas). A similar pattern of moistening and consequent warming occurred in simulations with prescribed June-September (JJAS) rainfall increases of $25 \%$ over historical values, a level of increase commensurate with projected future rainfall increases. There was a strong sensitivity of the moistening responses to the baseline hydrological state. Experiments with perturbed physics confirmed that the simulated warming in permafrost soils was caused by increases in the soil latent heat of fusion per unit volume and in the soil thermal conductivity due to the increased moisture. In transient Representative Concentration Pathway 8.5 (RCP8.5) scenario experiments, soil warming due to increased $\mathrm{CO}_{2}$ or JJAS rainfall was smaller in magnitude and spatial extent than in the equilibrium experiments. Active-layer deepening associated with soil moisture changes occurred over less than $8 \%$ of the current permafrost area because increased heat of fusion and soil thermal conductivity had compensating effects on active-layer depth. Ongoing modeling challenges make these results tentative.
\end{abstract}

\section{Introduction}

Permafrost-zone soils contain about $1700 \mathrm{Pg} \mathrm{C}$ (Tarnocai et al. 2009), and recent research has focused on investigating the potential vulnerability of this carbon to mineralization under climate warming (Schuur

\footnotetext{
* Supplemental information related to this paper is available at the Journals Online website: http://dx.doi.org/10.1175/JCLI-D12-00305.s1.

Corresponding author address: Zachary M. Subin, Princeton Environmental Institute, Guyot Hall, Rm. 129, Princeton, NJ 08544.

E-mail: subin@post.harvard.edu
}

et al. 2008, 2011). A number of modeling studies have investigated the magnitude of expected near-surface permafrost thaw (Schaefer et al. 2011), which may be a precursor to large losses of soil carbon, but these studies typically simulated or analyzed only surface air temperature (SAT; precise definitions of common terms in appendix A, section a) changes as the primary driver of soil temperature increases. However, other factors can be at least as important in determining soil temperature and active layer thickness (ALT; appendix A, section a): the seasonally asymmetric presence of snow insulation (the snow thermal rectifier) is a major control on soil temperature (Goodrich 1982; Zhang 2005). Many studies have shown the potential for changes in snowfall, snow properties, and snow season length to alter soil 
temperatures (Iijima et al. 2010; Lawrence and Slater 2010; Pavlov and Moskalenko 2002; Stieglitz et al. 2003; Westermann et al. 2011; Zhang et al. 2005).

Modeling has shown that increased soil moisture could cause mean annual warming of permafrost soils by interacting with the snow thermal rectifier because of increased latent heat of fusion per unit soil volume (LHF) (Goodrich 1982) and increased soil thermal conductivity (Zhang and Stamnes 1998). Two mechanisms that could alter soil moisture independently of air temperature under twenty-first-century climate change are the physiological effects of increased $\mathrm{CO}_{2}$ on plants and increased precipitation. An experimental synthesis found significant increases in soil moisture across a range of ecosystems due to reduced transpiration in openair elevated- $\mathrm{CO}_{2}$ experiments (van Groenigen et al. 2011). Modeling studies typically find decreased transpiration resulting from increased $\mathrm{CO}_{2}$ (Boucher et al. 2009; Cao et al. 2010; de Boer et al. 2011; Gopalakrishnan et al. 2011; Sellers et al. 1996b), consistent with recent observed increases in continental runoff (Gedney et al. 2006). Such reduced transpiration could result in SAT increases due to an increased Bowen ratio (Boucher et al. 2009; Cao et al. 2010; Sellers et al. 1996b). Additional warming could result from decreased albedo due to increased leaf area associated with $\mathrm{CO}_{2}$ fertilization (Bala et al. 2006; Notaro et al. 2005, 2007). Nevertheless, we are unaware of any studies investigating the effects of elevated- $\mathrm{CO}_{2}$ physiological forcing on soil temperatures.

A robust prediction in future climate simulations is increased precipitation at high latitudes throughout the year (Christensen et al. 2007), although the net effects on soil moisture are uncertain because of likely increases in potential evapotranspiration (ET) (Hinzman et al. 2005) and possible increases in drainage due to the retreat of underlying impervious permafrost (Avis et al. 2011; Smith et al. 2005). Some studies have discussed permafrost soil temperature increases co-occurring with increases in rainfall (Dankers et al. 2011; Iijima et al. 2010; Saito 2008; Westermann et al. 2011; Zhang et al. 2001), but these studies did not isolate changes in soil thermal properties associated with increased moisture from other influences on soil temperature, including changes in summer Bowen ratio and in snow properties. Observational evidence for increased ALT or warmer soils in areas with higher soil moisture is mixed (Hinkel and Nelson 2003; Hinkel et al. 2001; Jorgenson et al. 2010; Shiklomanov et al. 2007), which could be due to the confounding warming effects of surface water and cooling effects of increased near-surface moss and soil organic content in wet ecosystems (Jorgenson et al. 2010). One recent Arctic experimental manipulation partially attributed observed summer soil warming to increased subsurface thermal conductivity associated with flooding treatment (Zona et al. 2012).

In this study, we investigated whether increased soil moisture from increased $\mathrm{CO}_{2}$ or summer rainfall could cause soil warming in addition to that caused by increases in air temperature associated with climate change, and we quantified the mechanisms by which soil moisture affects soil temperature. To illustrate the thermal dynamics occurring in the model experiments, we include conceptual and simplified analyses of the seasonal cycle in section $3 c(3)$.

\section{Methods}

We performed experiments with the Community Land Model 4 (CLM4) (Lawrence et al. 2011), the land surface component of the Community Climate System Model 4 (CCSM4) (Gent et al. 2011) and the Community Earth System Model 1 (CESM1) (http://www.cesm. ucar.edu/models/cesm1.0/). Transpiration is calculated iteratively during the evaluation of surface and canopy energy fluxes, using formulations for stomatal conductance (Collatz et al. 1991; Oleson et al. 2010; Sellers et al. 1996a) and photosynthesis (Collatz et al. 1991; Farquhar et al. 1980) that include soil-moisture stress (Oleson et al. 2008). CLM4 soil physics includes vertically resolved thermal and hydrological diffusion in 10 soil layers down to $3.8 \mathrm{~m}$, with five hydrologically inactive bedrock layers continuing down to $42 \mathrm{~m}$ (Lawrence et al. 2011; Oleson et al. 2010). The effects of observed vertically resolved gridcell-mean soil organic content on soil physical properties are prescribed (Lawrence and Slater 2008). At each time step, thermal diffusion is solved in the absence of phase change, and then temperatures are corrected for LHF (Oleson et al. 2010), with allowance for the persistence of unfrozen soil moisture below the nominal freezing point (Niu and Yang 2006) (sensitivity to this parameterization in appendix A, section b). While CLM4 contains a number of subgrid land types, we only analyzed changes occurring in the vegetated land unit (appendix A, section a). The snow model includes up to five resolved layers with state variables of temperature, ice density, water density, snow grain radius, and deposited aerosol concentration (Flanner and Zender 2006; Flanner et al. 2007; Lawrence et al. 2011). Predictions of snow cover, snow accumulation, and permafrost extent in the offline CLM4 compare satisfactorily with observations, while positive snowfall biases in the coupled CCSM4 increase soil temperatures and ALT and decrease permafrost extent, somewhat degrading their realism (Lawrence et al. 2011, 2012a,b). In the simulations performed here, we included preliminary changes to CLM4 soil hydrology that correct 
TABLE 1. Experimental design; complete simulation details in appendix A, section d.

\begin{tabular}{|c|c|c|c|c|c|c|c|c|}
\hline No. & $\begin{array}{l}\text { Simulation } \\
\text { name }\end{array}$ & Forcing & $\begin{array}{c}\mathrm{CO}_{2} \\
(\mathrm{ppm})^{\mathrm{a}}\end{array}$ & $\begin{array}{l}\text { JJAS } \\
\text { rainfall }\end{array}$ & $\begin{array}{l}\text { Altered } \\
\text { physics }\end{array}$ & $\begin{array}{c}\text { Base } \\
\text { no. }\end{array}$ & $\begin{array}{c}\Delta \text { WFPS } \\
\left(\times 10^{-2}\right)^{\mathrm{b}}\end{array}$ & $\begin{array}{c}\Delta \text { Soil } \\
T\left({ }^{\circ} \mathrm{C}\right)^{\mathrm{c}}\end{array}$ \\
\hline 1 & Control & $\mathrm{NCEP}^{\mathrm{d}}$ & 285 & NCEP & - & - & - & - \\
\hline 2 & NoSnowIns & NCEP & 285 & NCEP & NoSnowIns & - & - & - \\
\hline 3 & $\mathrm{CO}_{2}$ & NCEP & 857 & NCEP & - & 1 & $3.0(13.1)$ & $0.27(1.5)$ \\
\hline 4 & HiRain & NCEP & 285 & $\mathrm{NCEP}+25 \%$ & - & 1 & $3.2(10.9)$ & $0.29(1.3)$ \\
\hline 5 & LoRain & NCEP & 285 & NCEP - 25\% & - & 1 & $-5.9(-9.7)$ & $-0.56(-1.4)$ \\
\hline 6 & tkSat & NCEP & 285 & NCEP & tkSat & - & - & - \\
\hline 7 & tkSat_CO 2 & NCEP & 857 & NCEP & tkSat & 6 & $2.9(14.1)$ & $0.17(0.8)$ \\
\hline 8 & NoHfus & NCEP & 285 & NCEP & NoHfus & - & - & - \\
\hline 9 & NoHfus_CO ${ }_{2}$ & NCEP & 857 & NCEP & NoHfus & 8 & $3.1(13.6)$ & $0.17(0.8)$ \\
\hline 10 & tkSat_NoHfus & NCEP & 285 & NCEP & tkSat; NoHfus & - & - & - \\
\hline 11 & tkSat_NoHfus_CO${ }_{2}$ & NCEP & 857 & NCEP & tkSat; NoHfus & 10 & $3.5(12.6)$ & $0.05(0.2)$ \\
\hline 12 & 1850 & $\mathrm{CCSM} 4^{\mathrm{e}}$ & 285 & CCSM4 & - & - & - & - \\
\hline 13 & 1850_CO $\mathrm{CO}_{2}$ & CCSM4 & 857 & CCSM4 & - & 12 & 3.1 & 0.24 \\
\hline 14 & 1850_HiRain & CCSM4 & 285 & CCSM $4+25 \%$ & - & 12 & 2.4 & 0.21 \\
\hline 15 & $\mathrm{RCP} 8.5$ & $\mathrm{RCP} 8.5^{\mathrm{f}}$ & Transient & RCP8.5 & - & - & - & - \\
\hline 16 & RCP8.5_FixCO 2 & RCP8.5 & 285 & RCP8.5 & - & $15^{\mathrm{h}}$ & -1.1 & -0.08 \\
\hline 17 & RCP8.5_FixRain & RCP8.5 & Transient & Detrended $^{\mathrm{g}}$ & - & $15^{\mathrm{h}}$ & -1.8 & -0.08 \\
\hline
\end{tabular}

${ }^{\text {a }} \mathrm{CO}_{2}$ concentrations refer only to those experienced by plants, while radiative concentrations were implicit in the prescribed atmospheric forcing.

${ }^{\mathrm{b}}$ Annual- and vertical-mean WFPS differences with respect to simulation defined by base number, averaged over the permafrost area (appendix A, section a) in the Control simulation (averages over the comparison region in parentheses).

${ }^{c}$ Annual- and vertical-mean (to $3.8 \mathrm{~m}$ ) soil temperature differences with respect to simulation defined by base number, averaged over the permafrost area in the Control simulation (averages over the comparison region in parentheses).

d Repeated 1948-72 cycles from Qian et al. (2006).

e Repeated 1850-74 cycles from a historical CCSM4 simulation (appendix A, section e).

${ }^{\mathrm{f}}$ Years 1850-2099 from a historical and RCP8.5 CCSM4 simulation (appendix A, section e).

g Transient rainfall adjusted to maintain decadal climatology at 1850-74 values (appendix A, section f).

${ }^{\mathrm{h}}$ Averaged over the 2050-99 period.

for unrealistic conduction of liquid water through frozen soils (appendix A, section c).

We performed offline simulations using prescribed atmospheric forcing, leaf area, and canopy height in order to isolate the direct interactions of soil moisture and soil temperature (Table 1; detailed model-configuration information in appendix A, section d). For equilibrium historical simulations, we used repeated cycles of 1948-72 atmospheric forcing from a bias-corrected reanalysis dataset of historical conditions (Qian et al. 2006). For equilibrium 1850-74 and for transient climate change simulations, we used atmospheric forcing generated from a coupled CCSM4 simulation for the 1850-2005 historical period and the 2006-99 Representative Concentration Pathway 8.5 (RCP8.5) scenario (Riahi et al. 2011) (appendix A, section e). June-September (JJAS) rainfall for the simulated 1850 s permafrost region (nonglaciated land area north of $45^{\circ} \mathrm{N}$ with mean annual SAT $\leq 0^{\circ} \mathrm{C}$ ) increased by $27 \%$ in this scenario from the 1850 s to the 2090s (supplemental Fig. 1). The atmospheric forcing used here is subject to the biases in CCSM4 (de Boer et al. 2012; Gent et al. 2011; Lawrence et al. 2012a,b; Peacock 2012); we briefly discuss the likely implications of these biases for our simulations in section 4 .

\section{Interactions of soil moisture and soil temperature under equilibrium historical conditions}

\section{a. Results}

To set the context for the results presented here, we found that eliminating snow insulation (experiment NoSnowIns-Control; Table 1), while maintaining other snow properties unchanged (appendix A, section $\mathrm{f}$ ), caused $7^{\circ} \mathrm{C}$-mean and $18^{\circ} \mathrm{C}$-maximum decreases in annual-mean soil temperatures north of $45^{\circ}$ latitude (supplemental Fig. 2a); differences between SAT and soil surface temperature in Control (supplemental Fig. 2b) were commensurate with previous studies (Zhang 2005). This result indicates a very large effect of the snow thermal rectifier in CLM4 compared to projected future SAT increases, implying a large potential sensitivity to processes that modify or interact with this effect.

Increasing atmospheric $\mathrm{CO}_{2}$ concentrations experienced by plants $\left(\mathrm{CO}_{2}\right.$-Control) from 285 (preindustrial levels) to $857 \mathrm{ppm}$ [projected for 2100 in the A2 scenario (Nakicenovic and Swart 2000)] caused increases in soil water-filled pore space (WFPS) of $\sim(0.1-0.2)$ (mean 
0.03 in Control permafrost; Table 1) in many regions throughout the globe because of reduced transpiration (Fig. 1a). Increasing JJAS rainfall by $25 \%$ (HiRainControl) caused similarly widespread WFPS increases (Fig. 1b), although the increases extended farther north into the Canadian archipelago where there was insufficient vegetation to cause reduced transpiration in $\mathrm{CO}_{2}$-Control. Increasing JJAS rainfall from $75 \%$ of the climatological value to $100 \%$ (Control-LoRain) caused even larger increases in WFPS (mean 0.06 in Control permafrost), especially in Northeastern Siberia (Fig. 1c), indicating substantial sensitivity to the baseline hydrological state.

In these three experiments, increases in WFPS of $0.1-0.2$ in permafrost soils were associated with local increases in vertical- and annual-mean soil temperatures of $\sim\left(1^{\circ} \mathrm{C}-2^{\circ} \mathrm{C}\right.$ ) (mean $0.3^{\circ}-0.6^{\circ} \mathrm{C}$ in Control permafrost; Figs. $2 \mathrm{a}-\mathrm{c}$ ), particularly northeast Siberia, northern Canada, and northern Alaska; these regions were characterized by cold winter air, nonnegligible winter snow accumulation, nonnegligible leaf area (for $\mathrm{CO}_{2}$-Control) or summer rainfall (for HiRainControl), and unsaturated soils in the baseline simulation (supplemental Figs. 3a,b). Warming was largest in the Control-LoRain experiment, which also had the largest simulated soil moisture increases. Local soil temperature changes outside of present-day permafrost regions were smaller than $0.5^{\circ} \mathrm{C}$ in magnitude, and we did not analyze changes in those regions.

\section{b. Perturbed physics simulations}

To test the hypothesis that these soil temperature increases were caused by increased LHF and soil thermal conductivity due to increased soil moisture, we repeated the elevated- $\mathrm{CO}_{2}$ experiment with perturbed physics that selectively eliminated these mechanisms (see appendix A, section $\mathrm{f}$, for model configuration details). In tkSat_CO $\mathrm{CO}_{2}$-tkSat, soil thermal conductivity was prescribed to saturated values (either for frozen or unfrozen soils, respectively) while LHF varied with soil moisture; in NoHfus_ $\mathrm{CO}_{2}$-NoHfus, LHF was eliminated beneath the top soil layer while thermal conductivity varied with soil moisture; and in tkSat NoHfus_CO $\mathrm{CO}_{2}$-tkSat_NoHfus, both thermal conductivity and LHF were prescribed. While the patterns of WFPS increases in these three experiments were similar to those in $\mathrm{CO}_{2}$-Control (Figs. 1a,d-f), the magnitude of warming was reduced by about $36 \%$ (Table 1) in both tkSat_ $\mathrm{CO}_{2}$-tkSat and NoHfus_CO $\mathrm{CO}_{2}$-NoHfus (Figs. 2d,e). In tkSat_NoHfus_CO ${ }_{2}$-tkSat_NoHfus, the warming was reduced by $81 \%$ (Table 1) compared to $\mathrm{CO}_{2}$-Control (Fig. 2f). These results demonstrate that these two mechanisms coupling soil moisture and soil temperature were necessary to cause the warming we observed in section $3 a$.

c. Analysis

\section{1) VerticAl AND SEASONAL PATTERNS OF SOIL TEMPERATURE CHANGE}

To better understand the mechanisms coupling soil moisture to soil temperature, we computed a mean annual cycle averaged over all grid cells showing greater than $1^{\circ} \mathrm{C}$ soil temperature increases in $\mathrm{CO}_{2}$-Control (Fig. 2a), weighting each grid cell equally (hereafter denoted the comparison region). The comparison region, representing $7 \%$ of the permafrost area in Control, was characterized by the largest magnitude of soil warming resulting from soil moistening due to the combination of factors described in section 3a. Decreased transpiration in $\mathrm{CO}_{2}$-Control caused WFPS to increase from 0.7 to 0.9 in the middle to lower active layer for the comparison region (supplemental Fig. 4b), which had a mean ALT in Control of $1.5 \mathrm{~m}$ (Fig. 3a). Near-surface soils warmed by up to $3.3^{\circ} \mathrm{C}$ in the winter while slightly cooling $\left(<0.4^{\circ} \mathrm{C}\right)$ in the summer (Fig. 3b). This seasonal cycle was rectified to a nearly constant $1.3^{\circ} \mathrm{C}$ warming deeper than $4.5 \mathrm{~m}$. The mean ALT increased by $0.1 \mathrm{~m}$, and the fall freeze-up was delayed by about 3 days.

Soil temperature changes for the comparison region in the elevated- $\mathrm{CO}_{2}$ experiments with perturbed physics (Fig. 3c,d) showed a complementary verticalseasonal pattern from the two mechanisms coupling soil moisture and soil temperature, roughly adding linearly to produce the pattern in Fig. 3b. With variable LHF only (tkSat_ $\mathrm{CO}_{2}$-tkSat), winter warming and summer cooling were relatively vertically symmetric (Fig. 3c), as increased energy diverged from the freeze front in the fall and winter and converged to the thaw front in the summer (Fig. 4c); the increase in the energy-transport requirement caused delays in freeze and thaw and reduced ALT by $0.4 \mathrm{~m}$. With variable soil conductivity only (NoHfus_ $\mathrm{CO}_{2}$ - $\mathrm{NoHfus)}$, near-surface winter warming and summer cooling contrasted with winter cooling and summer warming at the top of the permafrost table (Fig. 3d), causing an ALT increase of $0.5 \mathrm{~m}$; winter energy fluxes increased upward in the winter and downward in the summer (Fig. 4d). In both cases, we can infer that the longer seasonal extent and larger magnitude of winter warming as compared with summer cooling required the seasonally asymmetric presence of snow insulation; when the $\mathrm{CO}_{2}$-Control experiment was repeated with snow insulation eliminated, no net warming occurred (not shown). 
(a) $\mathrm{CO}_{2}-$ Control

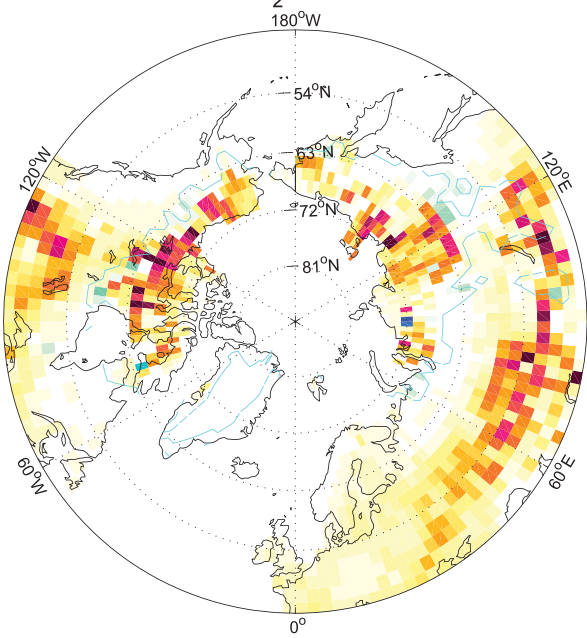

(c) Control - LoRain

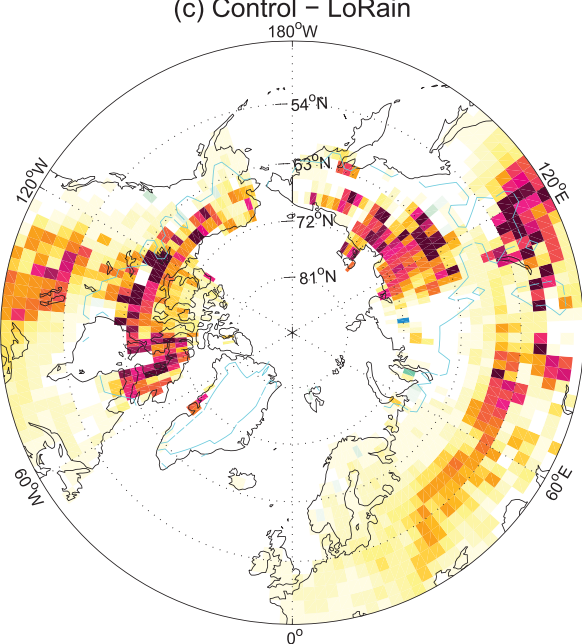

(e) NoHfus_CO $\mathrm{CO}_{2}$ - NoHfus

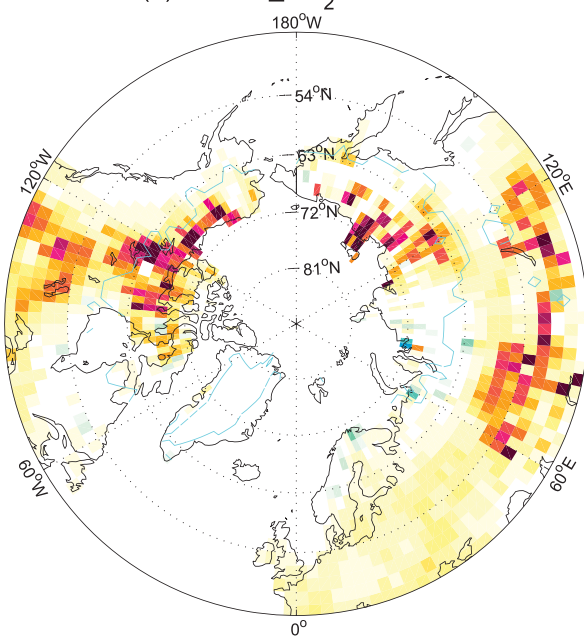

(b) HiRain - Control

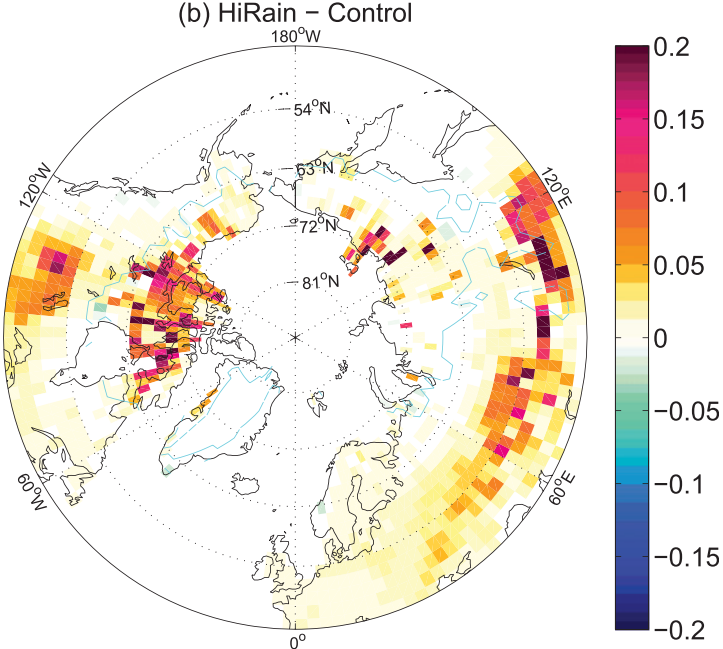

(d) tkSat_CO - tkSat

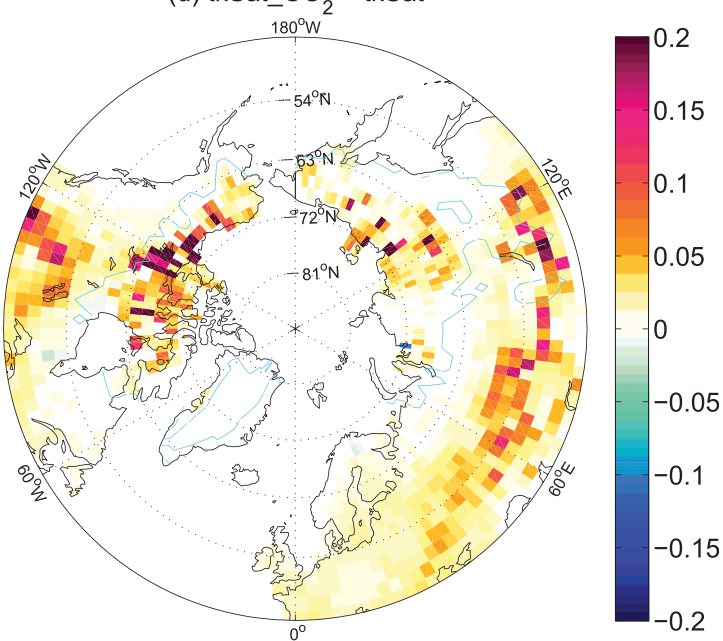

(f) tkSat_NoHfus_CO - tkSat_NoHfus

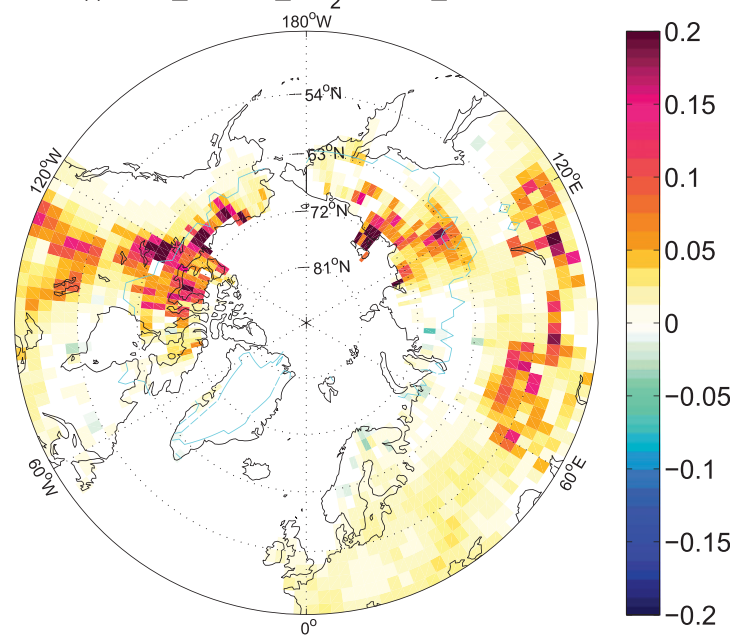

FIG. 1. Vertical- (to 3.8-m depth) and annual-mean soil water-filled pore space differences for experiments under equilibrium historical conditions: (a) increased $\mathrm{CO}_{2}$, (b) increased JJAS rainfall, (c) increased JJAS rainfall relative to reduced baseline, (d) increased $\mathrm{CO}_{2}$ with saturated soil thermal conductivity, (e) increased $\mathrm{CO}_{2}$ with no LHF, and (f) increased $\mathrm{CO}_{2}$ with both modifications to soil physics. Cyan lines encircle regions with ALT $<5 \mathrm{~m}$ in the baseline (i.e., drier) simulations for each panel. 
(a) $\mathrm{CO}_{2}-$ Control

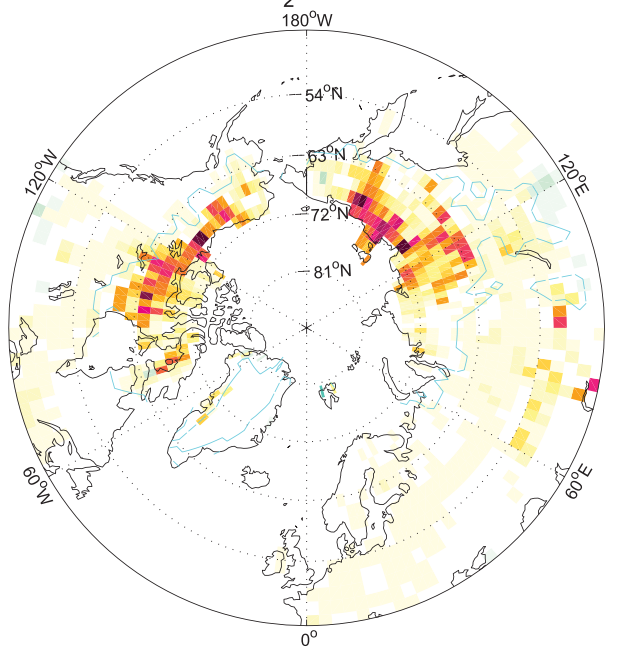

(c) Control - LoRain

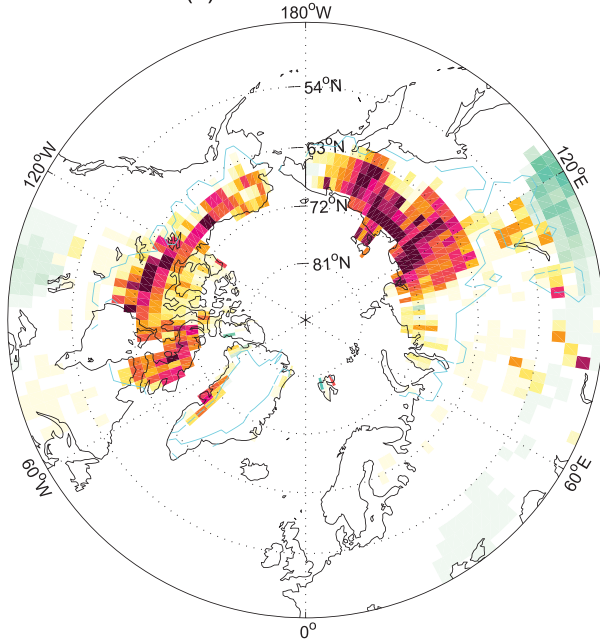

(e) NoHfus_CO $\mathrm{CO}_{2}-$ NoHfus

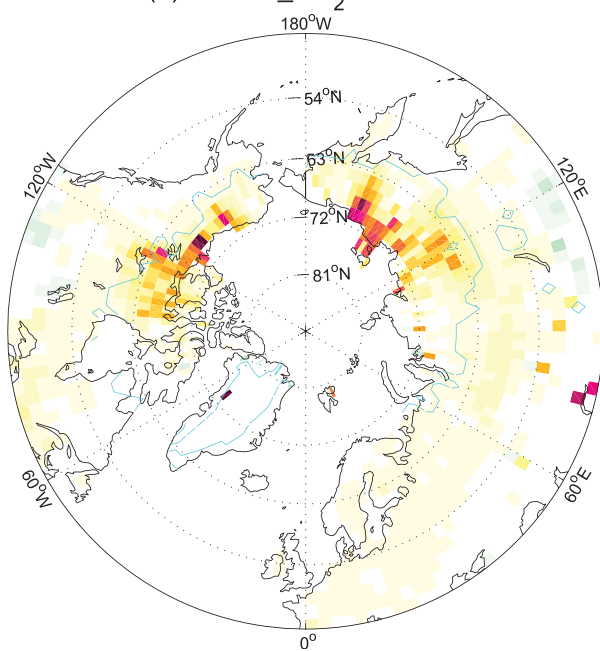

(b) HiRain - Control

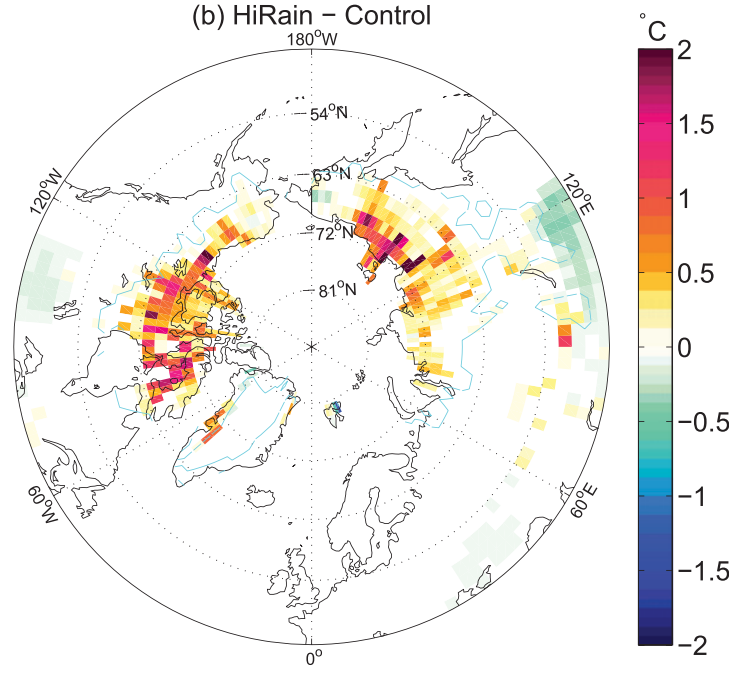

(d) tkSat_CO $\mathrm{CO}_{2}-\mathrm{tkSat}$

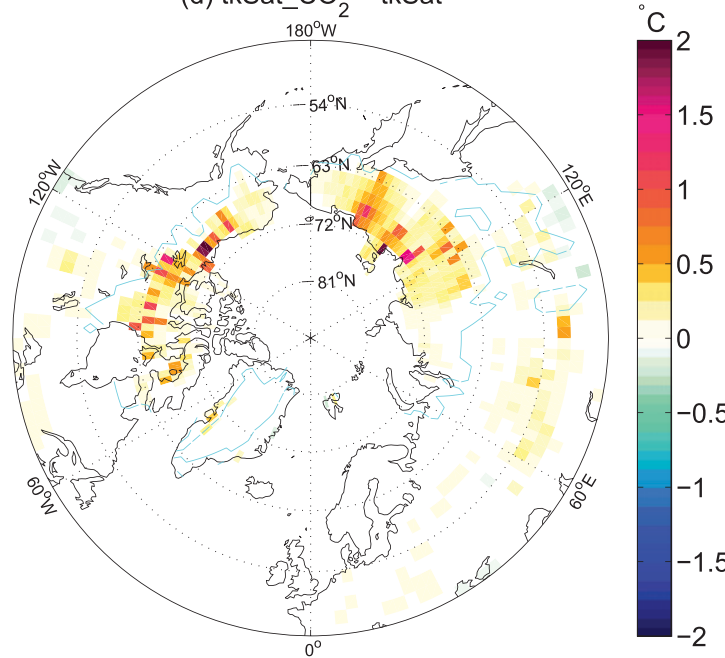

(f) tkSat_NoHfus_CO - tkSat_NoHfus

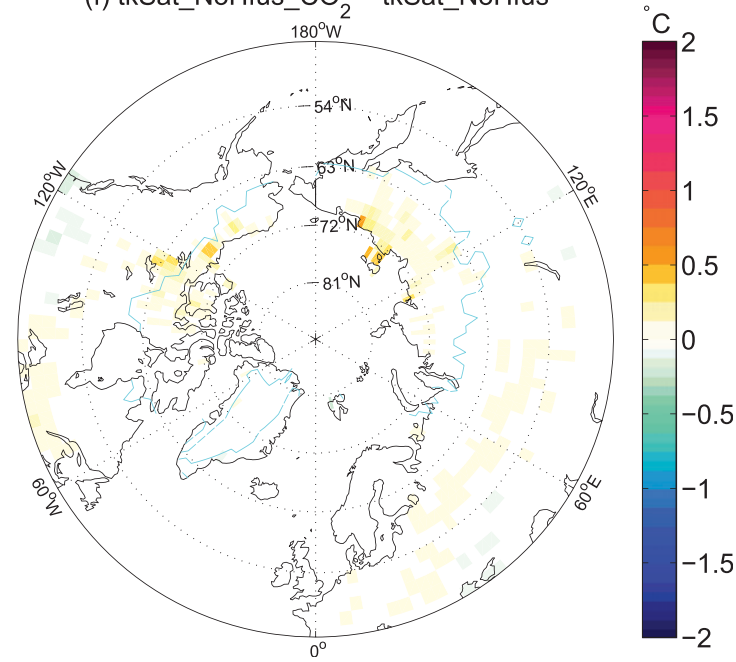

FIG. 2. As in Fig. 1, but for soil temperature differences $\left({ }^{\circ} \mathrm{C}\right)$. Cyan lines encircle regions with ALT $<5 \mathrm{~m}$ in the baseline (i.e., cooler) simulations for each panel. 

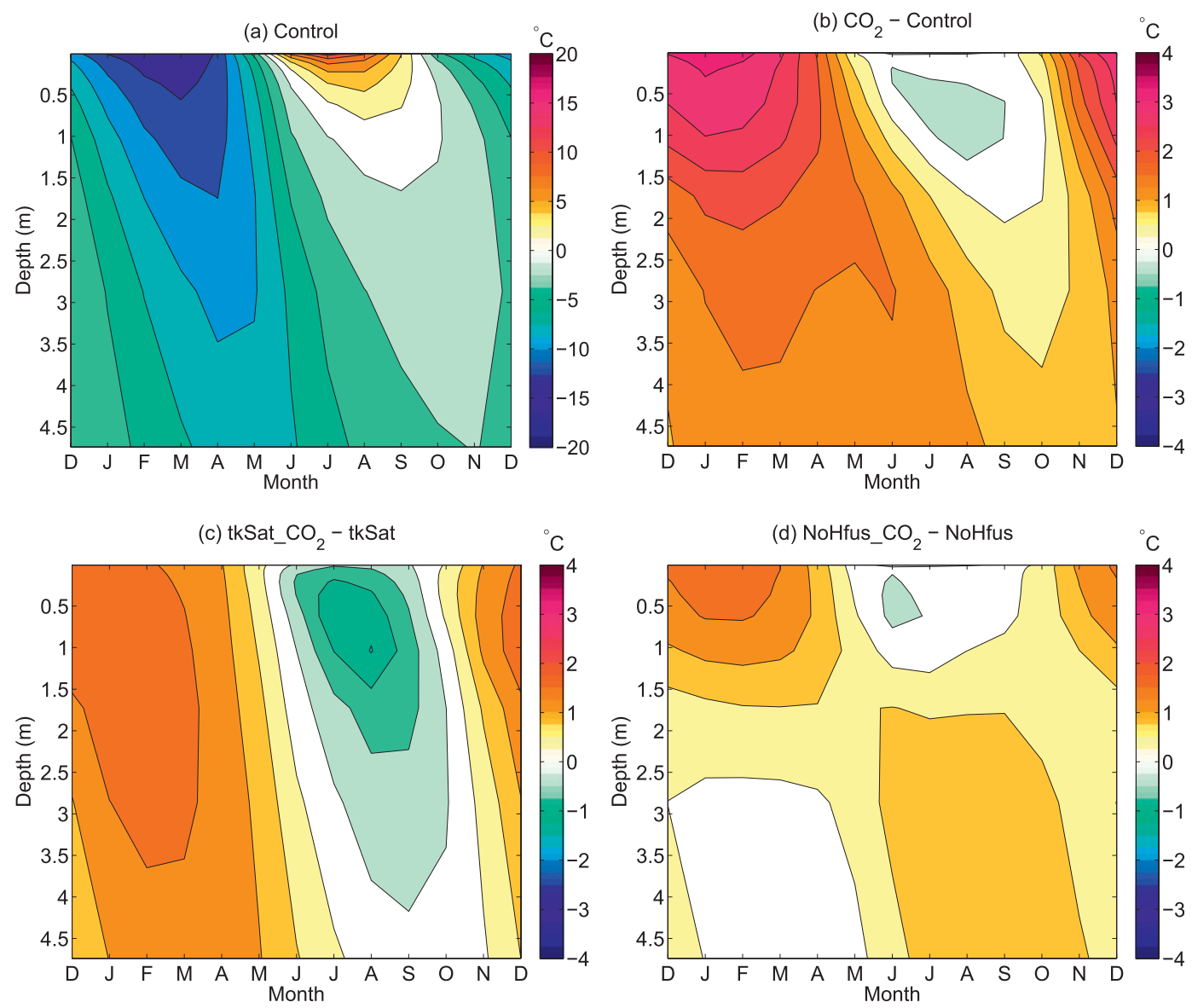

FIG. 3. Monthly mean soil temperatures or soil temperature differences $\left({ }^{\circ} \mathrm{C}\right)$ for experiments under equilibrium historical conditions, averaged over grid cells experiencing $>1{ }^{\circ} \mathrm{C}$ soil temperature increases in $\mathrm{CO}_{2}$-Control: (a) absolute temperatures occurring in Control, (b) differences due to increased $\mathrm{CO}_{2}$, (c) differences due to increased $\mathrm{CO}_{2}$ with saturated soil thermal conductivity, and (d) differences due to increased $\mathrm{CO}_{2}$ with no LHF.

\section{2) Changes In SURFACE ENERGY FLUXES}

We examined the annual cycle of surface energy flux changes in the comparison region. Because of increased $\mathrm{CO}_{2}\left(\mathrm{CO}_{2}\right.$-Control), the downward subsurface energy flux (appendix A, section a) increased by as much as $4 \mathrm{~W} \mathrm{~m}^{-2}$ in the summer and decreased by about $2 \mathrm{~W} \mathrm{~m}^{-2}$ throughout the winter (Fig. 5a), enhancing the baseline seasonal cycle of energy exchange between the soil and the atmosphere. In the summer, decreased transpiration caused an increase in the Bowen ratio. Some increased shortwave absorption occurred in the spring and summer because of earlier snowmelt (a positive feedback to the soil warming) and because of the moister and, therefore, darker soil. (Monthly mean snow thickness decreases were $<5 \%$.) In the perturbed physics experiments isolating mechanisms coupling soil moisture and soil temperature (Figs. 5b,c), the enhanced seasonal energy exchange simulated in $\mathrm{CO}_{2}-$ Control was decreased by about half; when both these mechanisms were removed (Fig. 5d), it was negligible, leaving only the summer Bowen ratio change due to decreased transpiration. Increasing JJAS rainfall (HiRainControl; Fig. 5e) caused nearly identical changes in downward subsurface energy flux as $\mathrm{CO}_{2}$-Control, although the summer Bowen ratio change was reversed. Summer SAT changes (Fig. 6) were smaller in magnitude than $0.2^{\circ} \mathrm{C}$ in these uncoupled experiments and not consistent in sign with surface, vegetation, and soil temperature (Fig. 4) changes, highlighting that Bowen ratio changes had only minor contributions to the soil temperature changes.

\section{3) CONCEPTUAL AND SIMPLE ANALYTICAL REPRESENTATIONS}

Conceptually, the LHF mechanism warms the soils after moistening because the extra LHF released during freeze tends to be trapped under the snow in the winter, while the extra LHF needed to melt the extra soil ice in 

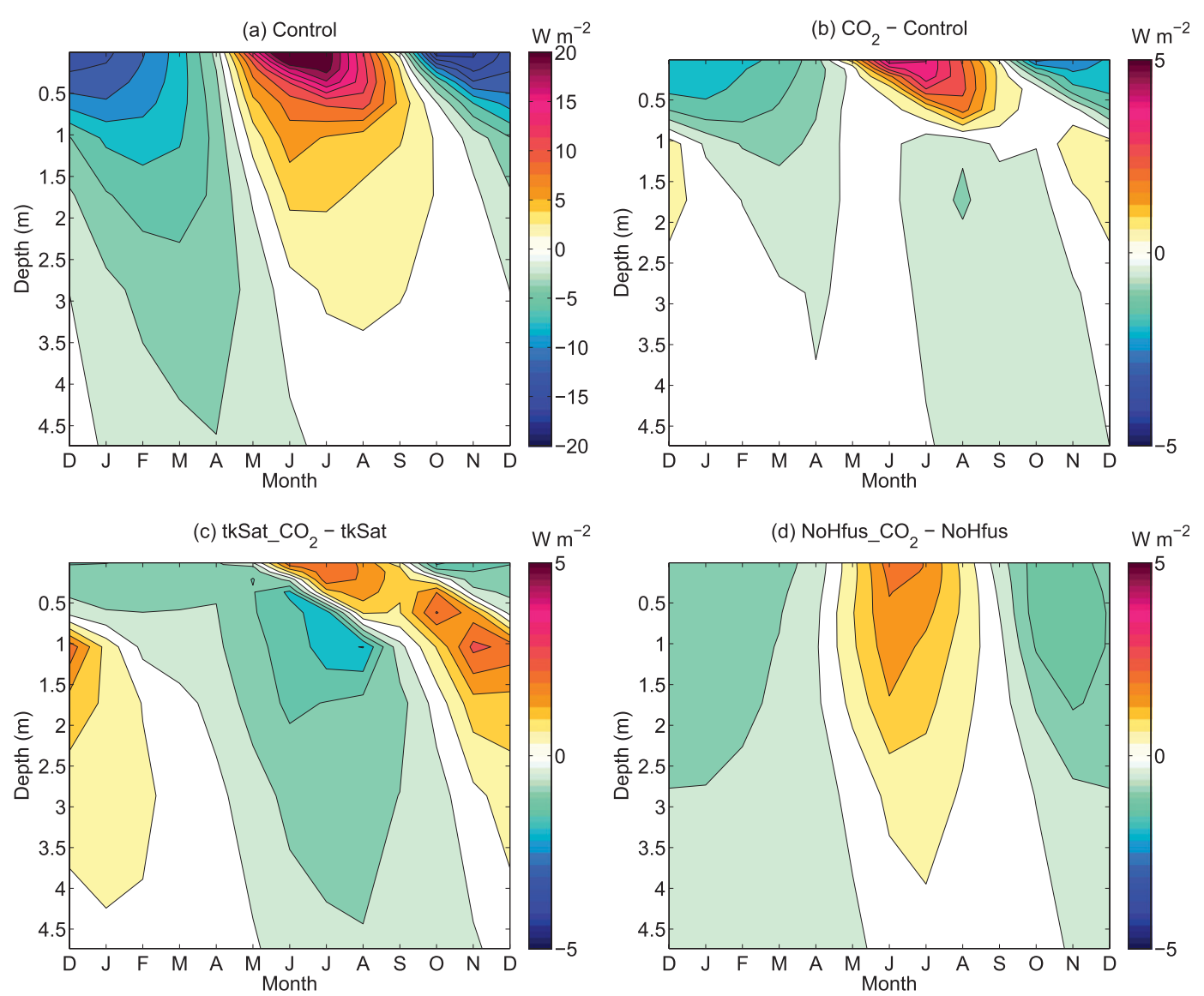

FIG. 4. As in Fig. 3, but for monthly mean downward soil heat fluxes or heat flux differences $\left(\mathrm{W} \mathrm{m}^{-2}\right)$.

the summer can be readily conducted into the soil from the atmosphere when snow is not present. Likewise, increased soil thermal conductivity acts to conduct more heat through the active layer during the summer but cannot contribute equally to heat loss during the winter because the snow is the dominant thermal resistance. Without a winter snowpack, the greater thermal conductivity of ice compared with liquid water would reverse the sign of this mechanism because of the "thermal offset" (Goodrich 1982).

Analytically, we first examine the LHF mechanism by considering the latent-heat-dominated regime where $L \gg c \Delta T: L$ is LHF, $c$ is the soil heat capacity per unit volume, and $\Delta T$ is the amplitude of seasonal temperature variation. In this regime, the Stefan equation approximates the instantaneous thaw depth $X$ during the unfrozen season (Riseborough et al. 2008):

$$
X=\sqrt{\frac{2 k T}{L}},
$$

where $k$ is the soil thermal conductivity and $T$ is proportional to the thawing-degree days (the time integral of the temperature above freezing). In the Stefan equation, increasing $L$ decreases the seasonal maximum $X$ by a factor proportional to $1 / \sqrt{L}$ but increases the integrated summer subsurface energy flux $(X L)$ by a factor of $\sqrt{L}$. In tkSat_CO $\mathrm{CO}_{2}$-tkSat, exemplifying the LHF mechanism, reduced transpiration from increased $\mathrm{CO}_{2}$ added $110 \mathrm{~kg} \mathrm{~m}^{-2}$ of water to the active layer in the comparison region (supplemental Fig. 4c). This would correspond to an increased $X L$, to first order, of $55 \mathrm{~kg} \mathrm{~m}^{-2} \times 3.3 \times 10^{5} \mathrm{~J} \mathrm{~kg}^{-1}=1.8 \times 10^{7} \mathrm{~J} \mathrm{~m}^{-2}$ (i.e., about half the extra water would remain in the active layer while half would contribute to making the active layer shallower) that must be exchanged seasonally with the atmosphere. As the winter subsurface energy flux must balance the summer flux in equilibrium, the extra summer absorption of $1.8 \times 10^{7} \mathrm{~J} \mathrm{~m}^{-2}$ implies an increased flux to the atmosphere of about $1.2 \mathrm{~W} \mathrm{~m}^{-2}$ averaged over November-April. During this period, such a change in energy flux across a mean $0.33 \mathrm{~m}$ of snow with conductivity $\sim 0.25 \mathrm{~W} \mathrm{~m}^{-1} \mathrm{~K}^{-1}$ would have been expected to be associated with a $1.5^{\circ} \mathrm{C}$ increase in the difference between the soil and snow surface temperatures. This is similar to the $1.2^{\circ} \mathrm{C}$ increase occurring in tkSat_CO $\mathrm{CO}_{2}$-tkSat. 
(a) $\mathrm{CO}_{2}$ - Control

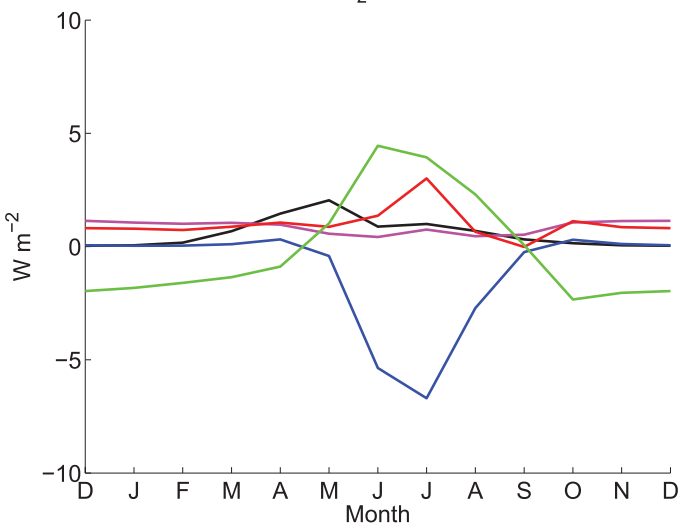

(c) NoHfus_ $\mathrm{CO}_{2}-$ NoHfus

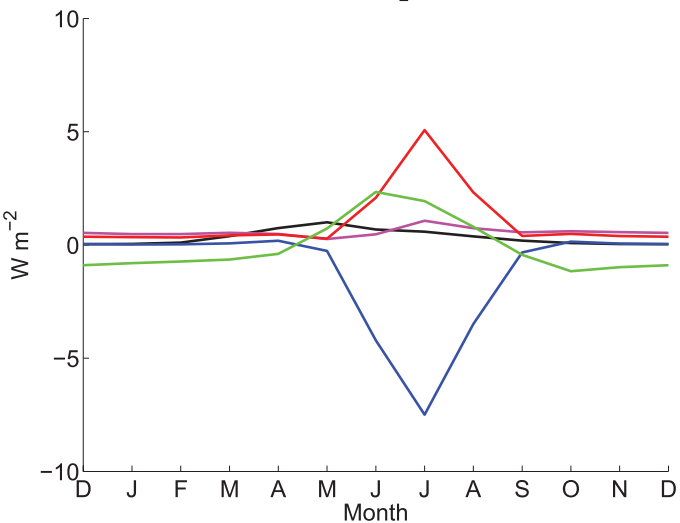

(b) tkSat_ $\mathrm{CO}_{2}-$ tkSat

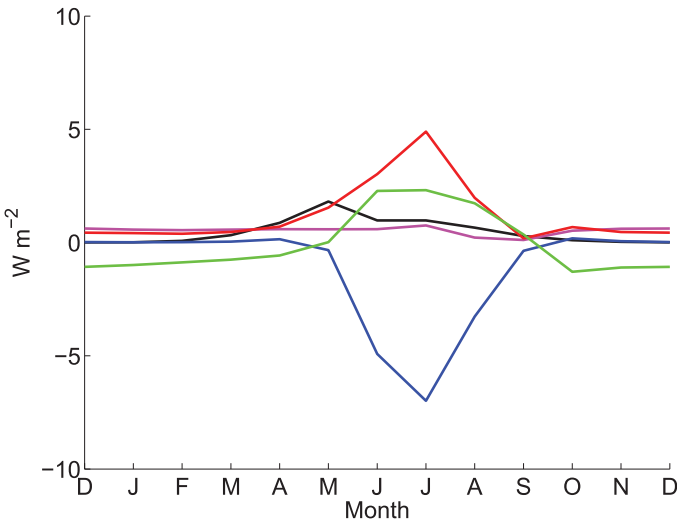

(d) tkSat_NoHfus_CO ${ }_{2}$ - tkSat_NoHfus

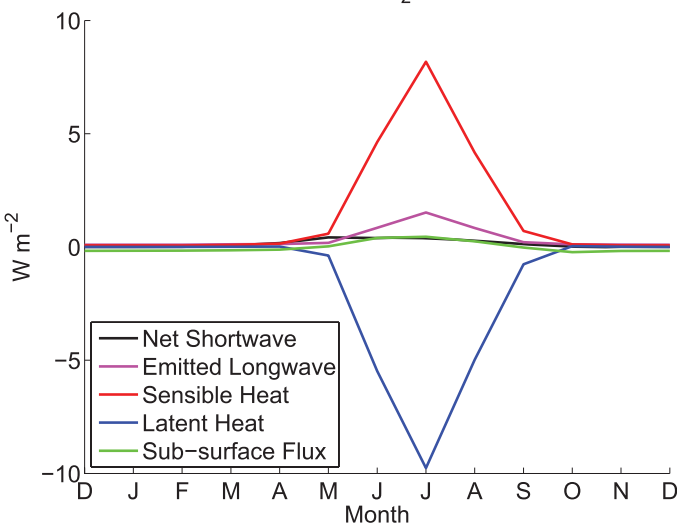

(e) HiRain - Control

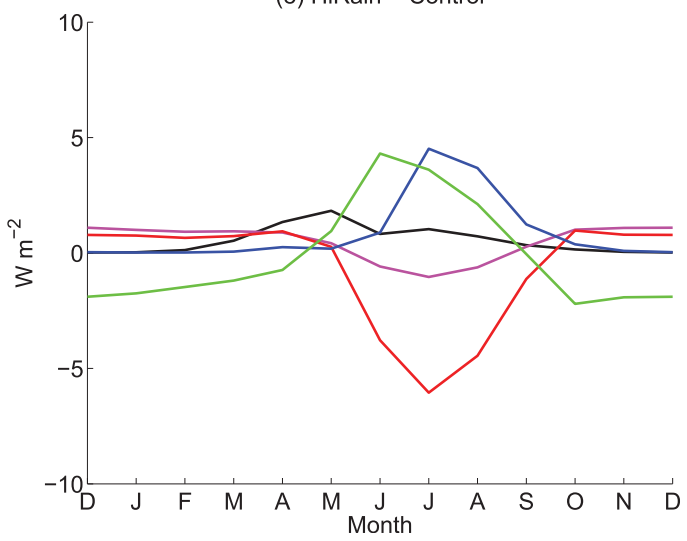

FIG. 5. Monthly mean surface energy flux differences $\left(\mathrm{W} \mathrm{m}^{-2}\right)$ for experiments under equilibrium historical conditions, averaged over grid cells experiencing $>1{ }^{\circ} \mathrm{C}$ soil temperature increases in $\mathrm{CO}_{2}$-Control: (a) increased $\mathrm{CO}_{2}$, (b) increased $\mathrm{CO}_{2}$ with saturated soil thermal conductivity, (c) increased $\mathrm{CO}_{2}$ with no $\mathrm{LHF}$, (d) increased $\mathrm{CO}_{2}$ with both modifications to soil physics, and (e) increased JJAS rainfall. Longwave, sensible, and latent energy fluxes are positive upward; net shortwave and subsurface energy fluxes are positive downward.

Secondly, we examine the thermal conductivity mechanism, which applies in both the $L \gg c \Delta T$ regime and in the opposite, purely diffusive, regime (Riseborough et al. 2008, their Eq. 2). In both cases, the integrated summer subsurface energy flux is proportional to $\sqrt{k}$. In the NoHfus_ $\mathrm{CO}_{2}$-NoHfus experiment exemplifying the thermal conductivity mechanism, the summer $k$ increased by $\sim 25 \%$ (not shown) in the comparison 
(a) $\mathrm{CO}_{2}-$ Control

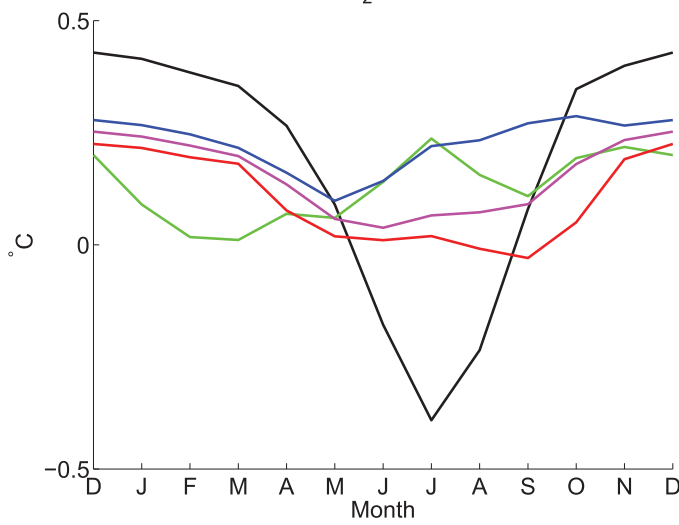

(c) NoHfus_ $\mathrm{CO}_{2}-$ NoHfus

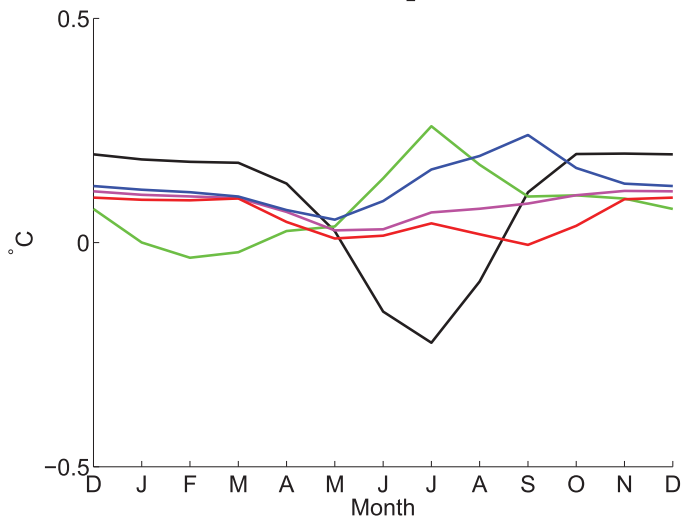

(b) tkSat_ $\mathrm{CO}_{2}-\mathrm{tkSat}$

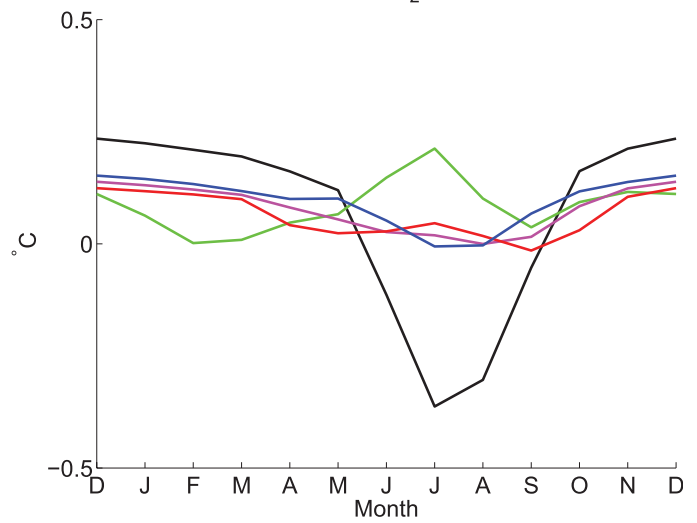

(d) tkSat_NoHfus_CO ${ }_{2}$ - tkSat_NoHfus

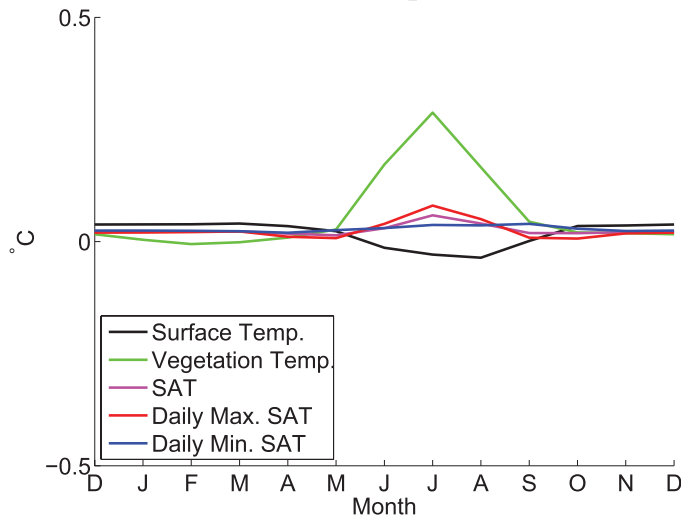

(e) HiRain - Control

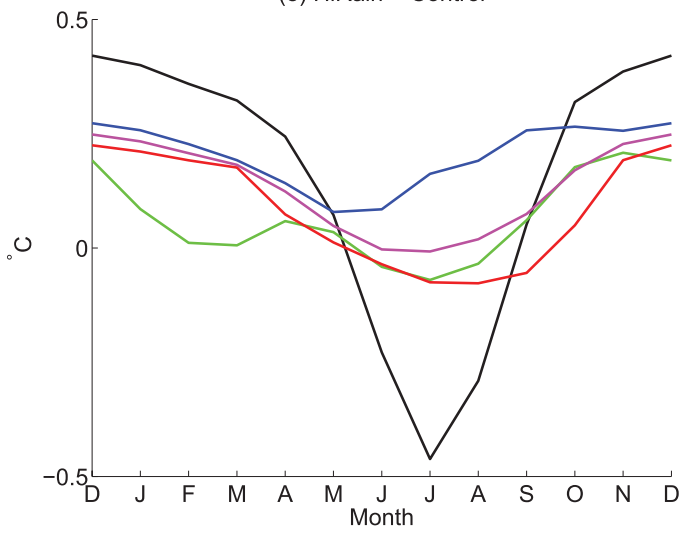

FIG. 6. As in Fig. 5, but for monthly mean near-surface temperature differences $\left({ }^{\circ} \mathrm{C}\right)$. Surface temperature is defined as the temperature of the top resolved soil or snow (if present) layer; vegetation temperature is defined at the leaf surface when present.

region because of extra soil moisture. As the total summer subsurface energy absorption in the comparison region was $9.5 \times 10^{7} \mathrm{~J} \mathrm{~m}^{-2}$ in the NoHfus simulation, we would expect this to have increased, to first order, by $12.5 \%$ or $1.2 \times 10^{7} \mathrm{~J} \mathrm{~m}^{-2}$. To exchange this increased energy with the atmosphere of $0.76 \mathrm{~W} \mathrm{~m}^{-2}$ divided over the November-April period, we would expect the difference between soil and snow surface temperatures to increase by $1.1^{\circ} \mathrm{C}$ given the $0.35 \mathrm{~m}$ of snow in NoHfus_ $\mathrm{CO}_{2}$-NoHfus. This is similar to the increase of $1.3^{\circ} \mathrm{C}$ occurring in the model experiment.

These two mechanisms explained at least $80 \%$ of the soil warming associated with soil moistening in our 
experiments, comparing the responses in tkSat_NoHfus_ $\mathrm{CO}_{2}$-tkSat_NoHfus to $\mathrm{CO}_{2}$-Control (Table 1). Additional mechanisms may have made minor contributions to the net warming. In particular, adding water or ice to soils increases the specific heat per unit volume, which would cause seasonal temperature changes similar in sign to those caused by the LHF mechanism. This specific heat mechanism is explicitly represented in CLM4, as the (time varying) soil heat capacity is a function of soil mineral, water, and ice concentrations (Oleson et al. 2010). However, the LHF and thermal conductivity mechanisms dominated this mechanism in our experiments because, in general, $L \gg c \Delta T$ in permafrost soils. To illustrate, an additional $55 \mathrm{~kg} \mathrm{~m}^{-2}$ of water in the active layer (as in tkSat_ $\mathrm{CO}_{2}$-tkSat) would increase the total heat capacity by up to $2.3 \times 10^{5} \mathrm{~J} \mathrm{~K}^{-1} \mathrm{~m}^{-2}$ (for the unfrozen season) or $1.1 \times 10^{5} \mathrm{~J} \mathrm{~K}^{-1} \mathrm{~m}^{-2}$ (for the unfrozen season). [Like increasing LHF, increasing heat capacity by adding water would tend to reduce the depth of seasonal temperature penetration (Riseborough et al. 2008), causing the first-order increase in seasonal energy exchange to be half as large as that proportional to the heat capacity increase.] Assuming an amplitude of $5^{\circ} \mathrm{C}$ warming during the unfrozen season and $10^{\circ} \mathrm{C}$ cooling during the frozen season, typical of the comparison region, this increased heat capacity would require an extra $\sim 1.1 \times 10^{6} \mathrm{~J} \mathrm{~m}^{-2}$ of energy exchange in both seasons. This is an order of magnitude smaller than the increased energy exchange requirements caused by each of the other two mechanisms described above.

\section{Effects on future permafrost thaw vulnerability}

\section{a. Preindustrial equilibrium experiments forced by CCSM4}

To investigate whether the mechanisms illustrated in section 3 may be important factors affecting permafrost thaw during future climate change, we performed additional land model experiments forced with atmospheric conditions generated by a CCSM4 historical and RCP8.5 1850-2099 simulation (appendix A, section e). We first repeated equilibrium experiments forced by the 1850-74 period in order to identify the sensitivity of the responses to the baseline atmospheric forcing. For elevated $\mathrm{CO}_{2}$ (1850_CO $\left.\mathrm{CO}_{2}-1850\right)$ and increased JJAS rainfall (1850_ HiRain-1850), regions of moistening (Figs. 7a,b) and warming (Figs. 8a,b) permafrost soils occurred, but these regions were smaller in spatial extent and magnitude of warming (Table 1) than, and generally did not overlap with, the regions warming in $\mathrm{CO}_{2}$-Control and HiRain-Control. This result reinforces the high sensitivity of these moistening mechanisms to the modeled hydrological state: comparing supplemental Fig. 3 with Figs. 1a-c and Figs. 7a,b illustrates that regions of permafrost experiencing moistening with increased $\mathrm{CO}_{2}$ or rainfall were those regions not saturated in the baseline simulations.

Biases in the CCSM4 atmospheric forcing may also have contributed to the weaker soil warming response in the 1850_CO ${ }_{2}-1850$ and 1850_HiRain-1850 experiments as compared with the $\mathrm{CO}_{2}$-Control and HiRain-Control experiments. Prescribed snowfall in the 1850 simulation (supplemental Fig. 5) was much larger than in the Control simulation (not shown) (Qian et al. 2006) throughout the Arctic (by $6.7 \mathrm{~mm} \mathrm{month}{ }^{-1}$, or $49 \%$, averaged over nonglaciated land area north of $60^{\circ}$ latitude), consistent with the excessive snowfall bias in historical CCSM4 simulations (Lawrence et al. 2012a,b). This increased prescribed snowfall was associated with increased simulated snow accumulation in these CLM4 simulations. As in Lawrence et al. (2012b), the increased snow accumulation apparently caused warmer winter Arctic soil temperatures, smaller permafrost area, and a shorter growing season. All of these factors would tend to reduce the sensitivity to the soil warming mechanisms described in section 3, although the increased snow insulation would itself tend to increase this sensitivity. Additional experiments would be required to quantify the relative importance of all the hydrological and thermal factors contributing to disparate responses in the CCSM4-forced experiments.

\section{$b$. Transient experiments under climate change}

We investigated the soil moistening and warming mechanisms under transient climate change by comparing a fully transient RCP8.5 land model simulation to one with fixed $1850 \mathrm{CO}_{2}$ concentrations of $285 \mathrm{ppm}$ (RCP8.5-RCP8.5_FixCO ${ }_{2}$ ) and to one with decadal JJAS rainfall forcing detrended (appendix A, section $\mathrm{g}$ ) to maintain the 1850-74 climatology (RCP8.5-RCP8.5 FixRain). Regions of moistening (Figs. 7c-h) and warming (Figs. $8 \mathrm{c}-\mathrm{h}$ ) permafrost soils occurred throughout the 2025-99 period, but warming due to moistening was smaller in magnitude than that occurring in the equilibrium historical experiments (Table 1$)$. Warming of $\sim 0.5^{\circ} \mathrm{C}$ from increased $\mathrm{CO}_{2}$ also occurred in some areas that had already lost near-surface permafrost by the end of the twenty-first century (Figs. 8e,g), associated with up to $0.2-\mathrm{m}$ increases in annual-mean thickness of unfrozen soil. Warming from increased $\mathrm{CO}_{2}$ in already-thawed permafrost was largest during the 2075-99 period (Fig. 8g) and during the fall season (not shown).

Temporal and regional mismatches between the areas susceptible to moistening (from increased $\mathrm{CO}_{2}$ 
(a) $1850 \_\mathrm{CO}_{2}-1850,1850-1874$

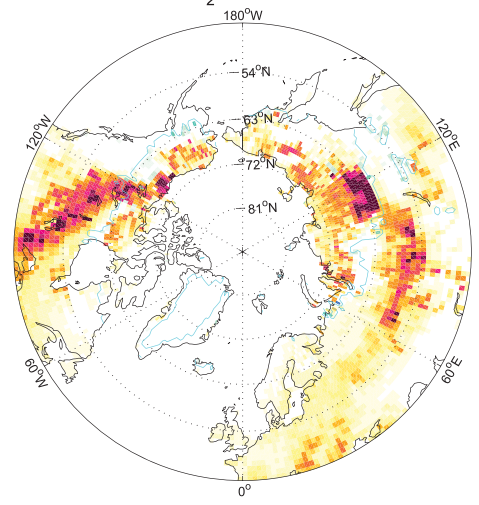

(c) RCP8.5 - RCP8.5_FixCO , 2025-2049

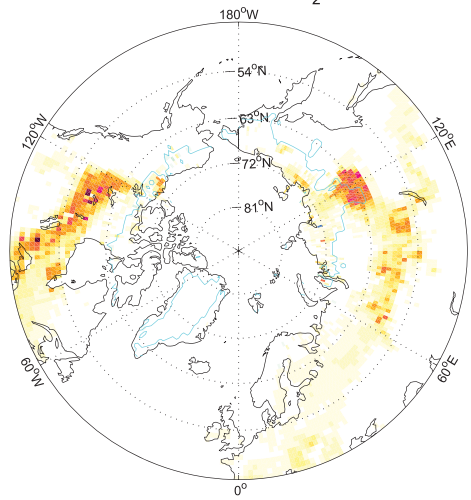

(e) RCP8.5 - RCP8.5_FixCO, $2050-2074$

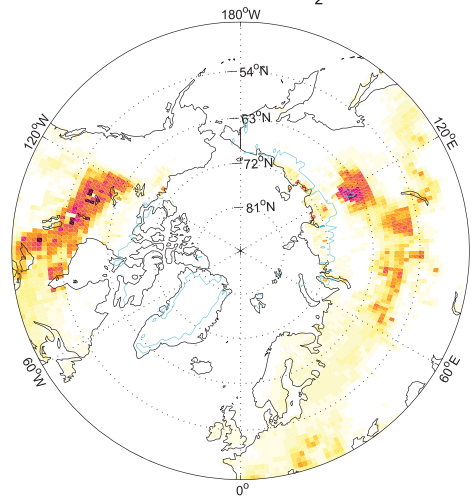

(g) RCP8.5 - RCP8.5_FixCO , 2075-2099

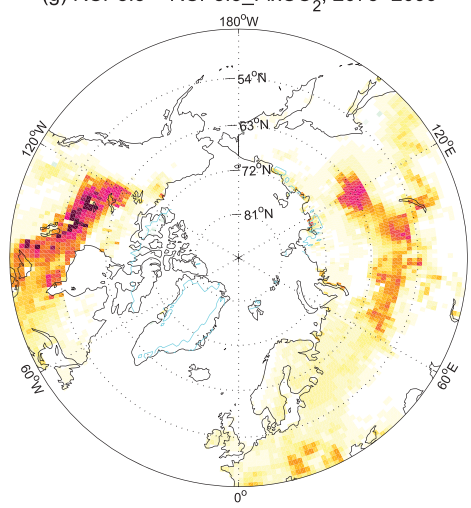

(b) 1850_HiRain - 1850, 1850-1874

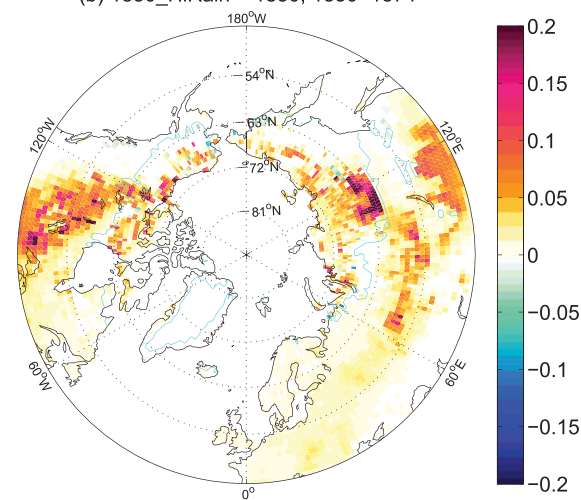

(d) RCP8.5 - RCP8.5_FixRain, 2025-2049

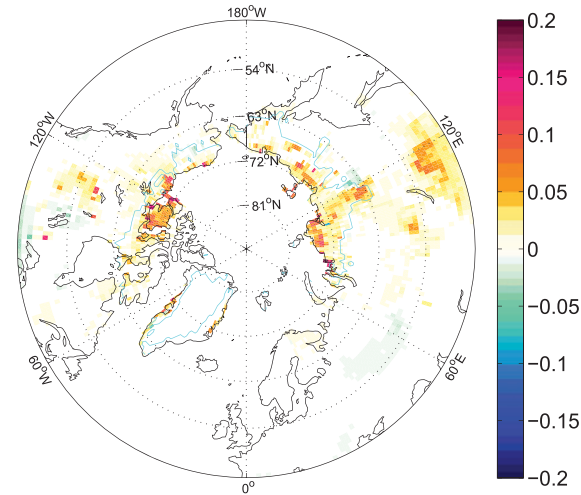

(f) RCP8.5 - RCP8.5_FixRain, 2050-2074

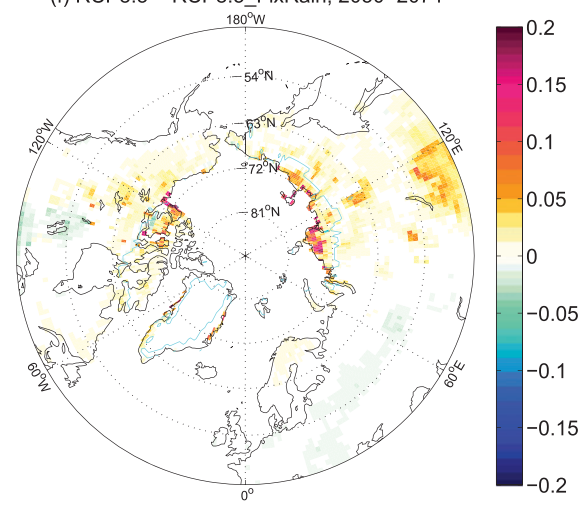

(h) RCP8.5 - RCP8.5 FixRain, 2075-2099

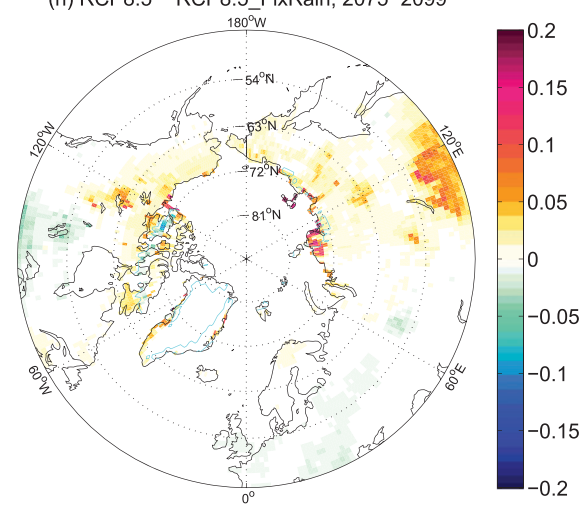


or rainfall) and the areas susceptible to consequent warming drove the smaller impacts of soil moistening in the future simulations as compared to those simulated under historical conditions. By the latter half of the 21st century, when the JJAS rainfall and the $\mathrm{CO}_{2}$ trends became large (supplemental Figs. 1 and 6), permafrost extent was already substantially reduced (Fig. 8) and air temperatures had dramatically increased (supplemental Fig. 5), especially during winter, reducing susceptibility to the mechanisms coupling soil moisture and soil temperature. The rapid loss of permafrost may have been accentuated by the CCSM4 excessive-snowfall bias (Lawrence et al. 2012b). The late-twenty-first-century regional mismatch was also exacerbated in RCP8.5RCP8.5_FixCO ${ }_{2}$ because the permafrost had retreated to high Arctic regions lacking much leaf area at present. Our prescribed leaf area simulations were inherently unable to show much sensitivity to $\mathrm{CO}_{2}$ concentrations in these barren northern regions, but vegetation productivity could increase there under a more hospitable climate, which would then increase the potential for $\mathrm{CO}_{2}$ increases to cause increases in soil moisture.

\section{c. Effects on permafrost vulnerability to thaw}

Increased ALT and vulnerability to complete thaw are additional critical metrics for assessing the potential for loss of permafrost carbon. In the equilibrium historical simulations, effects of the soil warming on ALT area distributions were small (Fig. 9a): area with ALT less than $2 \mathrm{~m}$ or $4 \mathrm{~m}$ decreased by up to $3 \times 10^{5} \mathrm{~km}^{2}(2 \%)$. Small changes also were predicted in the future simulations (Fig. 9b): an area with ALT less than $4 \mathrm{~m}$ decreased by up to $2 \times 10^{5} \mathrm{~km}^{2}$ in RCP8.5-RCP8.5_FixRain. This change represented an $8 \%$ decrease in area in $2075-99$, but relative to an already very low remaining area of $2.2 \times 10^{6} \mathrm{~km}^{2}$. These results indicate that soil moistening, despite causing substantial increases in mean annual soil temperatures, likely has only modest effects on ALT or permafrost vulnerability to thaw. This contrast is likely because of the compensating effects on ALT of the two mechanisms coupling soil moisture and soil temperature [sections $3 \mathrm{a}(1)$ and $3 \mathrm{a}(3)]$ : while increased soil thermal conductivity tends to increase ALT, increased LHF tends to decrease it, resulting in a small net increase in our experiments.

\section{Conclusions and discussion}

\section{a. Summary}

We showed that future climate forcings, which could increase WFPS in some permafrost regions by $\sim(0.1-0.2)$, could thereby increase mean annual soil temperatures locally by $\sim\left(1^{\circ} \mathrm{C}-2^{\circ} \mathrm{C}\right.$ ) (up to $3^{\circ} \mathrm{C}$ in our simulations). This potential warming, resulting principally from increased soil latent heat of fusion and thermal conductivity, is largest in the winter, with minimal effects on summer active layer thickness. This potential warming is currently not included in many analyses and depends on processes poorly simulated by current earth system models. A number of additional factors not simulated here could modify our results, discussed below.

\section{b. Generality of results}

While our experiments were conducted with prescribed atmospheric forcing, coupling with the atmosphere could alter soil temperatures via feedback from changes in SAT, if changes in surface energy fluxes occurred over large regions. Such feedbacks would likely enhance the soil warming associated with the spring and summer albedo decreases (Fig. 5), cause additional soil warming associated with decreased transpiration from increased $\mathrm{CO}_{2}$ (Fig. 5a), and reduce the soil warming associated with increased rainfall because of increased ET (Fig. 5e).

Our experiments were conducted with prescribed leaf area and canopy height in order to isolate the direct effects of increased soil moisture on soil temperature. In reality, increased $\mathrm{CO}_{2}$ or rainfall would likely result in increased leaf area and a consequent reduction in the net soil moisture increase, as some additional transpiration would be associated with increased plant growth. However, increased leaf area would also likely reduce albedo at high latitudes and facilitate snowmelt, which could cause spring and summer soil warming. If persistent increases in soil moisture enhanced anoxia (section $5 \mathrm{c}$ ), more moss and near-surface soil organic matter could accumulate,

\footnotetext{
$\leftarrow$

FIG. 7. Vertical- (to 3.8-m depth) and annual-mean soil water-filled pore space differences for experiments forced by an 1850-2099 CCSM4 RCP8.5 scenario: (a) increased $\mathrm{CO}_{2}$ in 1850-74 equilibrium, (b) increased JJAS rainfall in 1850-74 equilibrium, (c) transient effects of increasing $\mathrm{CO}_{2}$ during 2025-49, (d) transient effects of increasing JJAS rainfall during 2025-49, (e) transient effects of increasing $\mathrm{CO}_{2}$ during 2050-74, (f) transient effects of increasing JJAS rainfall during 2050-74, (g) transient effects of increasing $\mathrm{CO}_{2}$ during 2075-99, and (h) transient effects of increasing JJAS rainfall during 2075-99. Cyan lines encircle regions with ALT $<5 \mathrm{~m}$ in the baseline (i.e., drier) simulations for each panel.
} 
(a) 1850_CO $-1850,1850-1874$

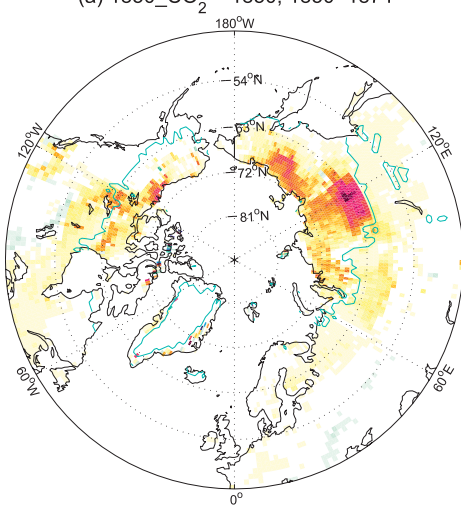

(c) RCP8.5 - RCP8.5_FixCO , 2025-2049

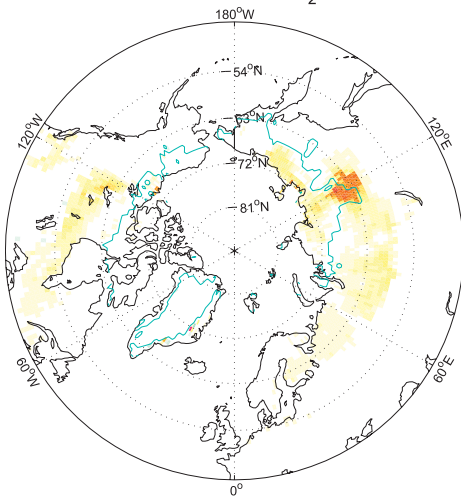

(e) RCP8.5 - RCP8.5_FixCO , 2050-2074

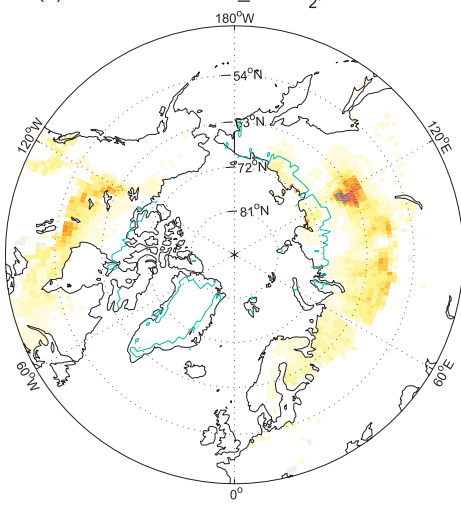

(g) RCP8.5 - RCP8.5_FixCO , 2075-2099

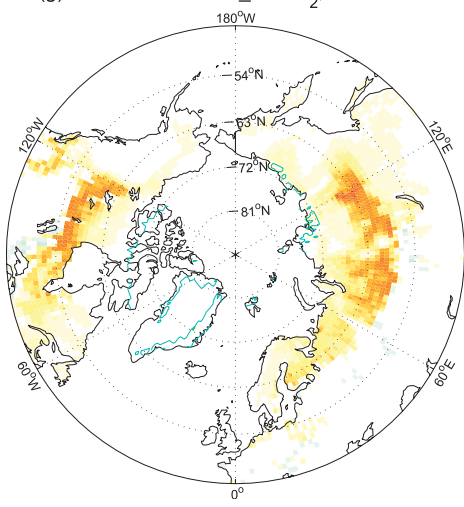

(b) 1850_HiRain - 1850, 1850-1874

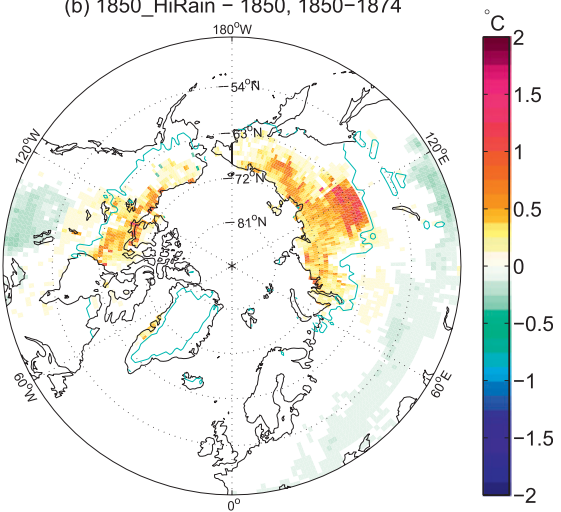

(d) RCP8.5 - RCP8.5_FixRain, 2025-2049

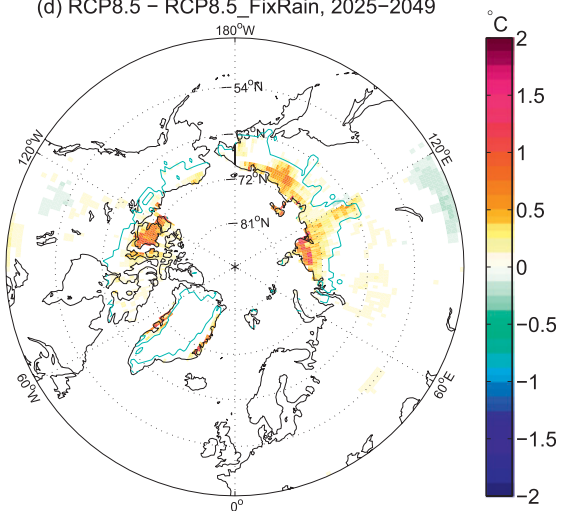

(f) RCP8.5 - RCP8.5_FixRain, 2050-2074

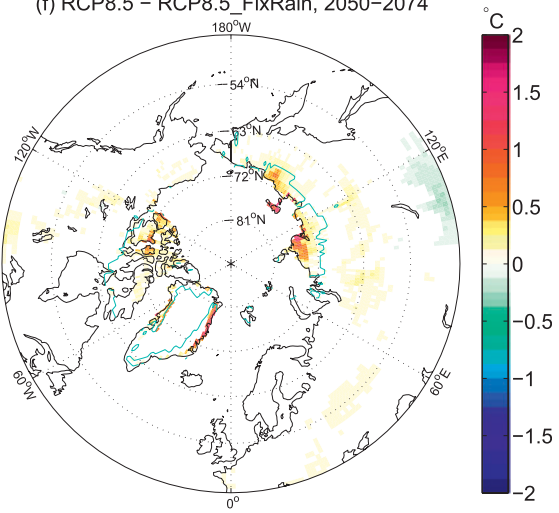

(h) RCP8.5 - RCP8.5 FixRain, 2075-2099

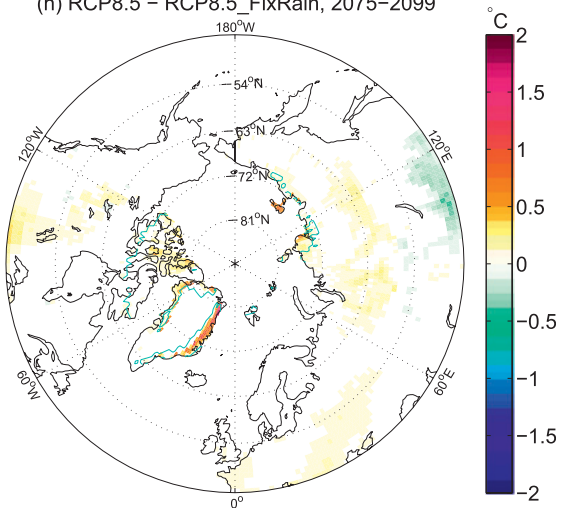

FIG. 8. As in Fig. 8, but for soil temperature differences $\left({ }^{\circ} \mathrm{C}\right)$. Cyan lines encircle regions with ALT $<5 \mathrm{~m}$ in the baseline (i.e., cooler) simulations for each panel. 
(a) Equilibrium Historical Conditions

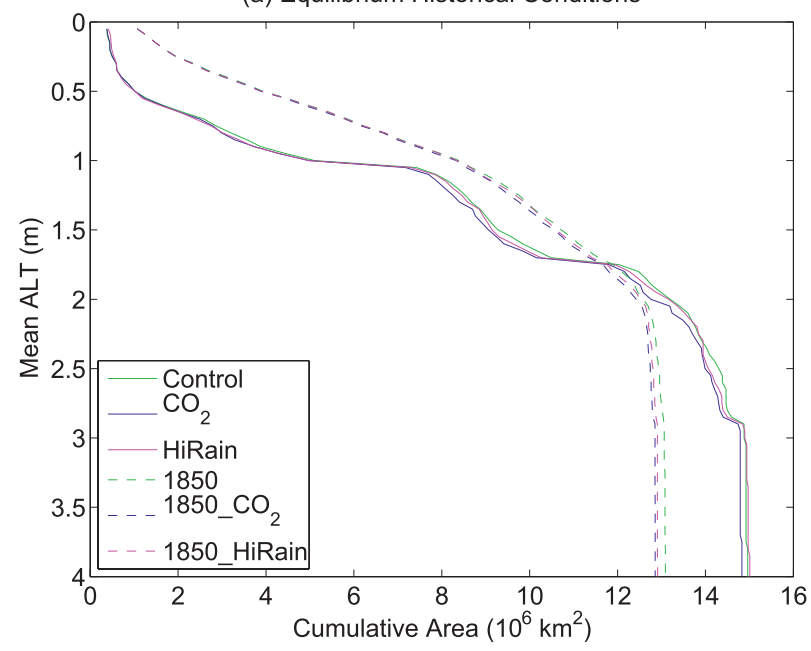

(b) RCP8.5

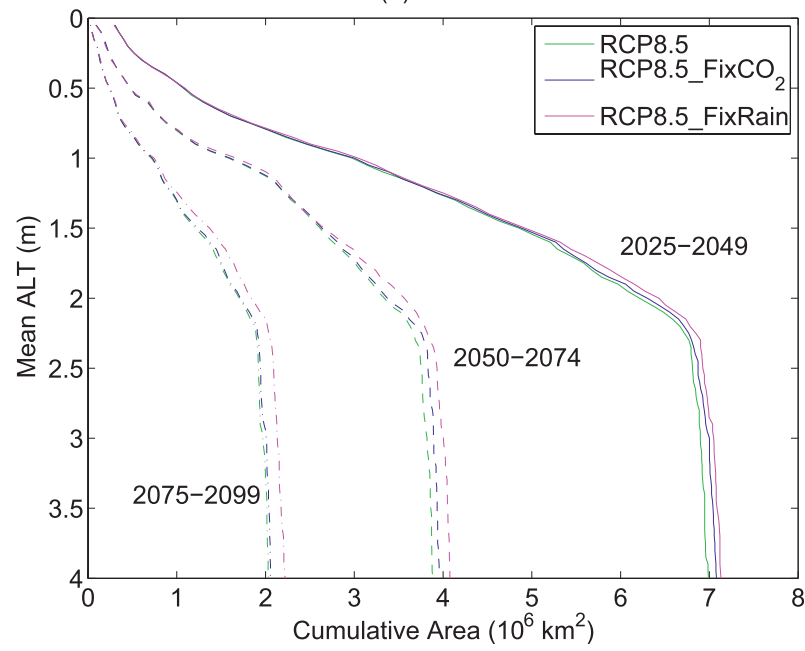

FIG. 9. Cumulative distribution functions of increasing 25-yr mean active-layer thickness (m) vs area $\left(10^{6} \mathrm{~km}^{2}\right)$ : (a) simulations under equilibrium historical conditions (Table 1) and (b) forced by a transient RCP8.5 scenario.

decreasing summer soil thermal conductivity and mitigating soil warming. More generally, the effects of increasing $\mathrm{CO}_{2}$ and rainfall on vegetation abundance will have uncertain effects on soil temperatures.

Our results show that the potential for soil moistening and subsequent warming is very sensitive to the initial hydrologic conditions. In soils that are already relatively moist, additional precipitation or reduced transpiration will not generate warming. Conversely, moist soils may be more susceptible to future drying, with subsequent cooling that could mitigate the effects of climate warming. As a result, additional observations of present-day soil moisture in permafrost regions would allow improved assessment of the vulnerability to future moistening or drying and resulting effects on soil temperature.

\section{c. Effects on soil carbon cycling}

Our results indicate that increases in soil moisture will likely cause relatively small active-layer deepening and thus be unlikely to increase accessibility of deep permafrost carbon, but annual-mean soil warming may affect greenhouse gas budgets resulting from changes in decomposition in the active layer and in already-thawed permafrost soils. For instance, $\mathrm{CO}_{2}$ increases caused persistent soil warming following near-surface permafrost thaw in some areas (Figs. 8e,g), which could enhance the mineralization of newly thawed permafrost carbon. Moistening could increase anoxia and, thus, $\mathrm{CH}_{4}$ emissions, which may be enhanced because the delayed fall freeze-up increases the time when unfrozen soil remains under impervious frozen soil. Decreased freeze depth in seasonally frozen soils, as simulated in the late twenty-first century from increased $\mathrm{CO}_{2}$, could also increase the potential for winter anaerobic decomposition under frozen soil.

\section{d. Implications for carbon cycle feedbacks}

If elevated $\mathrm{CO}_{2}$ increases soil carbon mineralization or enhances anoxic conditions, increased emissions of $\mathrm{CO}_{2}, \mathrm{CH}_{4}$, and $\mathrm{N}_{2} \mathrm{O}$ could occur independently of atmospheric warming. Previous analyses, such as Ringeval et al. (2011), considered the effects of increased soil moisture due to elevated $\mathrm{CO}_{2}$ on $\mathrm{CH}_{4}$ emissions via anoxia, but they did not examine the direct temperature response due to this moistening. While our results do not suggest that large increases in greenhouse gas emissions will likely result from the effects of soil moisture on soil temperature, there were large sensitivities to modeled hydrology in equilibrium simulations, and model biases and limitations may have reduced the magnitude of soil moisture and associated soil temperature changes (section 4). Consequently, the effects of soil moisture on soil temperature should be considered in future analyses.

Acknowledgments. The authors would like to recognize Joe Melton (University of Victoria) and the other members of the WETland and Wetland $\mathrm{CH}_{4}$ Inter-comparison of Models Project (WETCHIMP); experiments conducted by the authors for this project inspired the research detailed here. William Collins (Lawrence Berkeley Lab) contributed comments on a draft manuscript. Two anonymous reviewers provided comments that improved the manuscript. This work used resources of the National Energy Research Scientific Computing Center (NERSC) and was supported by the Director of the Office of Science, Office of Biological and Environmental Research, Climate and Environmental Science Division, U.S. Department 
of Energy, under Contract DE-AC02-05CH11231 to the Berkeley Lab.

\section{APPENDIX}

\section{Definitions and Additional Methodological Detail}

\section{a. Definitions}

\section{SAT}

ALT

LHF

Vegetated land unit

WFPS

Baseline

Permafrost area
Surface air temperature, calculated at $2 \mathrm{~m}$ above the surface.

Active layer thickness, here calculated annually as the maximum depth reached by the interpolated $0^{\circ} \mathrm{C}$ isotherm, including taliks (annually unfrozen ground).

Latent heat of fusion per unit volume of soil, that is, $3.3 \times 10^{5} \mathrm{~J} \mathrm{~kg}^{-1}$ multiplied by the kilograms $\mathrm{H}_{2} \mathrm{O}$

CLM4 contains five different subgrid land units, including vegetated, lake, wetland, urban, and glacier (Lawrence et al. 2011; Oleson et al. 2010). We only analyze the vegetated land unit here, which consists of vegetation and snow (if present) over soil and bedrock. We also generally exclude from analysis grid cells containing vegetated land units that do not experience at least one month in the mean annual cycle with surface temperatures above freezing.

Water-filled pore space, the fraction of available pore volume in the soil occupied by liquid or solid $\mathrm{H}_{2} \mathrm{O}$, that is, volumetric saturated fraction.

In the phrase "baseline hydrological state," in figure captions, and when otherwise applicable, baseline denotes the member of an experimental comparison pair of simulations with lower soil moisture due to lower $\mathrm{CO}_{2}$ or rainfall forcing.

For calculating mean differences over "permafrost area" in the Control simulation and for figure contours (regions with ALT $<5 \mathrm{~m}$ ), this area consists of nonglaciated soils (see vegetated land unit above) with climatological mean (annual maximum) ALT $<5 \mathrm{~m}$. per cubic meter of soil volume.
Comparison region

Downward subsurface energy flux

\section{b. Sensitivity to treatment of unfrozen soil moisture}

In CLM4, soil layers cooling below the freezing point are not forced to convert liquid water to ice (with release of LHF) until the soil moisture potential predicted to be associated with the temperature below freezing (Niu and Yang 2006) becomes more negative than the soil moisture potential based on the WFPS (Oleson et al. 2010). This parameterization was used for all of our simulations defined in Table 1 . In addition, we repeated the $\mathrm{CO}_{2}$-Control simulation with no allowance for the persistence of liquid water below $0^{\circ} \mathrm{C}$ : all liquid water was forced to freeze before soil layers could cool below $0^{\circ} \mathrm{C}$. This modification caused only slight changes in the spatial pattern and magnitude of soil warming as compared with the original $\mathrm{CO}_{2}$-Control simulation; mean differences in vertical- and annual-mean soil temperatures due to increased $\mathrm{CO}_{2}$ for grid cells in the comparison region decreased by $0.2^{\circ} \mathrm{C}$ in the modified experiment, but some permafrost grid cells showed greater soil warming in the modified experiment as compared with the original.

\section{c. Modifications to CLM4 hydrology}

Permafrost soils in CLM4 may be biased dry (Lawrence et al. 2011, 2012b); a likely contribution is excessive movement of liquid water through frozen soils (Swenson et al. 2012). The CLM4 formulation calculates an unfrozen fraction of soil pore volume (Niu and Yang 2006; Oleson et al. 2008) and allows liquid water to be conducted through that fraction (Oleson et al. 2010) without sufficiently accounting for the large effective tortuosity in soils with substantial ice-filled pore space (Lundin 1990). Similarly to the approach used in Swenson et al. (2012), we reduce the permeability of frozen soils by eliminating the Niu and Yang (2006) unfrozen fraction calculation and replacing it with a power-law ice impedance $I$ (no unit) that reduces the 
hydraulic conductivity according to (Hansson et al. 2004; Lundin 1990):

$$
I=10^{-\Omega F_{\text {ice }},}
$$

where $F_{\text {ice }}$ (no unit) is the ice-filled pore space (fraction of total pore volume) and here $\Omega=8$. As the CLM4 onedimensional soil water budget is closed by calculating horizontal drainage as a function of the diagnosed water table depth, we compute a "perched" water table depth $z_{p}(\mathrm{~m})$ in grid cells with saturated layers occurring above a frost table $z_{f}(\mathrm{~m})$ and calculate horizontal drainage from this perched water table $Q_{p}\left(\mathrm{~mm} \mathrm{H}_{2} \mathrm{O} \mathrm{s}^{-1}\right)$ according to

$$
Q_{p}=\alpha\left(z_{f}-z_{p}\right) k_{p},
$$

where $\alpha=10^{-3} \mathrm{~m}^{-1}$ and $k_{p}\left(\mathrm{~mm} \mathrm{H}_{2} \mathrm{O} \mathrm{s}^{-1}\right)$ is the verticalmean hydraulic conductivity in the perched water table, including the ice impedance (A1). In addition, while CLM4 assumed that hydraulic and thermal properties of organic soil (Lawrence and Slater 2008) corresponded to "fibric peat" (Letts et al. 2000), we included a linear transition to finer-pore-sized "sapric peat" (Letts et al. $2000)$ at $0.5-\mathrm{m}$ depth. These three modifications yield wetter active layers in permafrost grid cells.

\section{d. Details of CLM4 simulation configurations}

All simulations (Table 1) used CLM4 offline (i.e., with prescribed atmospheric conditions) with prescribed vegetation state [satellite phenology (SP)] (Lawrence et al. 2011). Using prescribed vegetation state allows transpiration and diagnostic photosynthesis to vary but with inactive model biogeochemistry. Historical equilibrium simulations with Qian et al. (2006) atmospheric forcing [National Centers for Environmental Prediction $(\mathrm{NCEP})$ in Table 1] were global with $1.9^{\circ} \times 2.5^{\circ}$ resolution. The CESM1 standard I_1850 case was used, with 1850 conditions for aerosol deposition and land use (i.e., plant functional type spatial distributions). An initial simulation (with identical configuration to the Control simulation) was spun up for 200 years with repeated 1948-72 atmospheric forcing. The ending state from this simulation was used as initial conditions for an additional 200 years of spinup for each of the NCEP simulations with the respective conditions for $\mathrm{CO}_{2}$ concentration, JJAS rainfall, and perturbed physics for each experiment. Note that for the rainfall perturbation simulations HiRain and LoRain, JJAS rainfall was only altered for time steps when the lower atmospheric temperature was greater than or equal to $0^{\circ} \mathrm{C}$ to prevent alteration of snow properties. Finally, an additional 25 -yr period was integrated and analyzed for each simulation.
Simulations using CCSM4 atmospheric forcing (appendix A, section e; CCSM4 and RCP8.5 in Table 1) were for a northern domain $\left(>45^{\circ} \mathrm{N}\right)$ extracted from the global $0.9^{\circ} \times 1.25^{\circ}$ resolution dataset. For the equilibrium historical simulations (CCSM4 in Table 1), an I_1850 case was modified to accept atmospheric forcing data from the archived CCSM4 simulation (appendix A, section e), with 1850 conditions for aerosol deposition and land use. These three equilibrium historical simulations were separately spun up for 200 years with repeated 1850-74 forcing from the CCSM4 data, with the respective conditions for $\mathrm{CO}_{2}$ concentration and JJAS rainfall for each simulation. Finally, an additional 25-yr period was integrated and analyzed for each simulation.

For the transient simulations (RCP8.5 in Table 1), an I_RCP8.5_CN case was modified to use satellite phenology and to accept atmospheric forcing data from the archived CCSM4 simulation (appendix A, section e), with transient 1850-2099 conditions for aerosol deposition and land use. The same initial conditions as for the 1850 simulation were used for the three transient simulations, which then proceeded for 250 years from 1850 to 2099.

\section{e. $2^{\circ}$ CCSM4 climate forcing}

For the CCSM4 and RCP8.5 simulations in Table 1, we used atmospheric forcing generated from a previously archived CCSM4 historical and RCP8.5 simulation. This simulation was fully coupled (with active land, atmosphere, ocean, and sea ice models) and used the $1.9^{\circ} \times 2.5^{\circ}$ resolution datasets for the land and atmosphere and the gx1v6 resolution dataset for the ocean. The land model included prognostic biogeochemistry $(\mathrm{CN})$, and the atmosphere used Community Atmosphere Model version 4 (CAM4) physics. Atmospheric concentrations of greenhouse gases were prescribed. We used the standard B_RCP8.5_CN case (http://www.cesm.ucar.edu/models/cesm1.0/). Other than the resolution, this simulation was configured similarly to those used in the CCSM4 RCP8.5 ensemble (Vavrus et al. 2011) archived for the Climate Model Intercomparison Project 5 (CMIP5); the projected $>70^{\circ} \mathrm{N}$ twenty-first-century warming (2090-99 minus 2000-09) in our $2^{\circ}$-resolution CCSM4 simulation was $9.8^{\circ} \mathrm{C}$, within the range projected in the $1^{\circ}$ ensemble (Vavrus et al. 2011). The global-mean temperature increase from the 1850-74 period to the 2075-99 period was $4.3^{\circ} \mathrm{C}$ (supplemental Figs. 5a,b). High-latitude rainfall increased at most locations from the 1850-74 period to the 2075-99 period (supplemental Figs. 5c,d), while snowfall increased in the coldest areas and decreased in warmer areas (supplemental Figs. 5e,f). The archived data used as forcing for CLM4 included halfhourly lower-atmosphere incident solar radiation data 
and 3-hourly data for lower-atmosphere downward longwave radiation, temperature, specific humidity, wind, pressure, and precipitation rates.

\section{f. Perturbed physics}

\section{1) NO SNOW INSULATION}

For the NoSnowIns simulation (Table 1), the thermal conductivity of each snow layer calculated by CLM4 (Oleson et al. 2010), as based on Snow Thermal Model (SNTHERM) (Jin et al. 1999), was multiplied by a factor of $10^{6}$. As the energy fluxes in CLM4 from the snow surface are calculated based on a fixed top-layer temperature from the last time step and then are updated after the soil thermal diffusion solution based on the change in top-layer temperature and the first derivative of sensible and latent heat fluxes with surface temperature (Oleson et al. 2010), and because heat fluxes into the soil were limited by the conductivity of the top soil layer, no numerical stability problems occurred.

\section{2) SOIL CONDUCTIVITY PRESCRIBED TO SATURATED VALUES}

Soil thermal conductivity in CLM4 (Oleson et al. 2010), based on Farouki (1981), depends on soil texture, soil organic matter content, temperature, WFPS, and ice-filled pore space. (CLM4 does not include advection of heat by infiltrating water.) For the tkSat, tkSat_CO $\mathrm{CO}_{2}$, tkSat_NoHfus, and tkSat_NoHfus_CO $\mathrm{CO}_{2}$ simulations (Table 1), the soil thermal conductivity was set for all hydrologically active soil layers (1-10) regardless of the water and ice concentrations at each time step. Instead, the value corresponding to WFPS $=1$ for unfrozen soils was used if the soil layer temperature exceeded $0^{\circ} \mathrm{C}$, while the value corresponding to ice-filled pore space of 1 for frozen soils was used otherwise.

\section{3) NO HEAT OF FUSION}

For the NoHfus, NoHfus_CO $\mathrm{CO}_{2}$, tkSat_NoHfus, and tkSat_NoHfus_CO $\mathrm{CO}_{2}$ simulations (Table 1), the latent heat of fusion for soil pore $\mathrm{H}_{2} \mathrm{O}$ was eliminated for soil layers 2-10. It was maintained in the top $0.01-\mathrm{m}$ soil layer and in the snow layers; the CLM4 bedrock layers are assumed dry with fixed thermal properties. While normally the requirement of absorbing or releasing $3.3 \times$ $10^{5} \mathrm{~J} \mathrm{~kg}^{-1} \mathrm{H}_{2} \mathrm{O}$ for thaw or freeze, respectively, limits soil temperature changes near freezing in CLM4 (Oleson et al. 2010), in these simulations the heat of fusion was set to $1 \mathrm{~J} \mathrm{~kg}^{-1}$ for soil layers $2-10$. Consequently, energy transport requirements for thaw and freeze negligibly restricted soil temperature change. We made sure that after our modifications, the soil energy balance check in CLM4 remained valid to $10^{-6} \mathrm{~W} \mathrm{~m}^{-2}$.

\section{g. Precipitation detrending}

The RCP8.5_FixRain simulation (Table 1) used "detrended" precipitation forcing from the archived CCSM4 historical and RCP8.5 coupled simulation data (appendix A, section e) as compared to the fully transient precipitation forcing used directly from the coupled simulation for the other RCP8.5 and CCSM4 simulations (Table 1). We calculated the 1850-74 JJAS rainfall climatology for each grid cell by averaging the rainfall for each 3-h time step during this period, separately for convective and large-scale liquid precipitation. To generate the detrended forcing for the RCP8.5_FixRain simulation, we calculated the anomalous ratio of decadal JJAS rainfall for each decade from 1850 to 2099 (i.e., $1850-59,1860-69, \ldots, 2090-99$ ) as compared with the 1850-74 climatology. Then, at each JJAS time step from 1850-2099, for each grid cell, and separately for convective and large-scale liquid precipitation, we multiplied the precipitation in the forcing data by the inverse of this ratio (when finite) to obtain the detrended forcing data. This method preserved daily, seasonal, and interannual rainfall variation while maintaining a fixed decadal-mean climatology.

\section{REFERENCES}

Avis, C. A., A. J. Weaver, and K. J. Meissner, 2011: Reduction in areal extent of high-latitude wetlands in response to permafrost thaw. Nat. Geosci., 4, 444-448.

Bala, G., K. Caldeira, A. Mirin, M. Wickett, C. Delire, and T. J. Phillips, 2006: Biogeophysical effects of $\mathrm{CO}_{2}$ fertilization on global climate. Tellus, 58B, 620-627.

Boucher, O., A. Jones, and R. A. Betts, 2009: Climate response to the physiological impact of carbon dioxide on plants in the Met Office Unified Model HadCM3. Climate Dyn., 32, 237 249.

Cao, L., G. Bala, K. Caldeira, R. Nemani, and G. Ban-Weiss, 2010: Importance of carbon dioxide physiological forcing to future climate change. Proc. Natl. Acad. Sci. USA, 107, 9513-9518.

Christensen, J. H., and Coauthors, 2007: Regional climate projections. Climate Change 2007: The Physical Science Basis, S. Solomon et al., Eds., Cambridge University Press, 847-940.

Collatz, G. J., J. T. Ball, C. Grivet, and J. A. Berry, 1991: Physiological and environmental-regulation of stomatal conductance, photosynthesis, and transpiration: A model that includes a laminar boundary-layer. Agric. For. Meteor., 54, 107-136.

Dankers, R., E. J. Burke, and J. Price, 2011: Simulation of permafrost and seasonal thaw depth in the JULES land surface scheme. Cryosphere, 5, 773-790.

de Boer, G., W. Chapman, J. E. Kay, B. Medeiros, M. D. Shupe, S. Vavrus, and J. Walsh, 2012: A characterization of the present-day arctic atmosphere in CCSM4. J. Climate, 25, 2676-2695.

de Boer, H. J., E. I. Lammertsma, F. Wagner-Cremer, D. L. Dilcher, M. J. Wassen, and S. C. Dekker, 2011: Climate forcing due to optimization of maximal leaf conductance in subtropical vegetation under rising $\mathrm{CO}_{2}$. Proc. Natl. Acad. Sci. USA, 108, 4041-4046. 
Farouki, O. T., 1981: The thermal properties of soils in cold regions. Cold Reg. Sci. Technol., 5, 67-75.

Farquhar, G. D., S. von Caemmerer, and J. A. Berry, 1980: A biochemical model of photosynthetic $\mathrm{CO}_{2}$ assimilation in leaves of $\mathrm{C}_{3}$ species. Planta, 149, 78-90.

Flanner, M. G., and C. S. Zender, 2006: Linking snowpack microphysics and albedo evolution. J. Geophys. Res., 111, D12208, doi:10.1029/2005JD006834.

— _ _ J. T. Randerson, and P. J. Rasch, 2007: Present-day climate forcing and response from black carbon in snow. J. Geophys. Res., 112, D11202, doi:10.1029/2006JD008003.

Gedney, N., P. M. Cox, R. A. Betts, O. Boucher, C. Huntingford, and P. A. Stott, 2006: Detection of a direct carbon dioxide effect in continental river runoff records. Nature, 439, 835838.

Gent, P. R., and Coauthors, 2011: The Community Climate System Model version 4. J. Climate, 24, 4973-4991.

Goodrich, L. E., 1982: The influence of snow cover on the ground thermal regime. Can. Geotech. J., 19, 421-432.

Gopalakrishnan, R., G. Bala, M. Jayaraman, L. Cao, R. Nemani, and N. H. Ravindranath, 2011: Sensitivity of terrestrial water and energy budgets to $\mathrm{CO}_{2}$-physiological forcing: An investigation using an offline land model. Environ. Res. Lett., 6, 044013.

Hansson, K., J. Simunek, M. Mizoguchi, L. C. Lundin, and M. T. van Genuchten, 2004: Water flow and heat transport in frozen soil: Numerical solution and freeze-thaw applications. Vadose Zone J., 3, 693-704.

Hinkel, K. M., and F. E. Nelson, 2003: Spatial and temporal patterns of active layer thickness at Circumpolar Active Layer Monitoring (CALM) sites in northern Alaska, 1995-2000. J. Geophys. Res., 108, 8168, doi:10.1029/2001JD000927.

— , F. Paetzold, F. E. Nelson, and J. G. Bockheim, 2001: Patterns of soil temperature and moisture in the active layer and upper permafrost at Barrow, Alaska: 1993-1999. Global Planet. Change, 29, 293-309.

Hinzman, L. D., and Coauthors, 2005: Evidence and implications of recent climate change in northern Alaska and other arctic regions. Climatic Change, 72, 251-298.

Iijima, Y., A. N. Fedorov, H. Park, K. Suzuki, H. Yabuki, T. C. Maximov, and T. Ohata, 2010: Abrupt increases in soil temperatures following increased precipitation in a permafrost region, central Lena River basin, Russia. Permafrost Periglacial Processes, 21, 30-41.

Jin, J., X. Gao, Z.-L. Yang, R. C. Bales, S. Sorooshian, R. E. Dickinson, S. F. Sun, and G. X. Wu, 1999: Comparative analyses of physically based snowmelt models for climate simulations. J. Climate, 12, 2643-2657.

Jorgenson, M. T., and Coauthors, 2010: Resilience and vulnerability of permafrost to climate change. Can. J. For. Res., 40, 1219-1236.

Lawrence, D. M., and A. G. Slater, 2008: Incorporating organic soil into a global climate model. Climate Dyn., 30, 145-160.

- and - 2010: The contribution of snow condition trends to future ground climate. Climate Dyn., 34, 969-981.

— functional and structural advances in version 4 of the Community Land Model. J. Adv. Model. Earth Syst., 3, M03001, doi:10.1029/2011MS000045.

, K. W. Oleson, M. G. Flanner, C. G. Fletcher, P. J. Lawrence, S. Levis, S. C. Swenson, and G. B. Bonan, 2012a: The CCSM4 land simulation, 1850-2005: Assessment of surface climate and new capabilities. J. Climate, 25, 2240-2260.
A. G. Slater, and S. C. Swenson, 2012b: Simulation of presentday and future permafrost and seasonally frozen ground conditions in CCSM4. J. Climate, 25, 2207-2225.

Letts, M. G., N. T. Roulet, N. T. Comer, M. R. Skarupa, and D. L. Verseghy, 2000: Parametrization of peatland hydraulic properties for the Canadian Land Surface Scheme. Atmos.-Ocean, 38, 141-160.

Lundin, L.-C., 1990: Hydraulic properties in an operational model of frozen soil. J. Hydrol., 118, 289-310.

Nakicenovic, N., and R. Swart, Eds., 2000: Special Report on Emissions Scenarios. Cambridge University Press, 599 pp.

Niu, G.-Y., and Z.-L. Yang, 2006: Effects of frozen soil on snowmelt runoff and soil water storage at a continental scale. J. Hydrometeor., 7, 937-952.

Notaro, M., Z. Liu, R. Gallimore, S. J. Vavrus, J. E. Kutzbach, I. C. Prentice, and R. L. Jacob, 2005: Simulated and observed preindustrial to modern vegetation and climate changes. J. Climate, 18, 3650-3671.

— S. Vavrus, and Z. Liu, 2007: Global vegetation and climate change due to future increases in $\mathrm{CO}_{2}$ as projected by a fully coupled model with dynamic vegetation. J. Climate, 20, 70-90.

Oleson, K. W., and Coauthors, 2008: Improvements to the Community Land Model and their impact on the hydrological cycle. J. Geophys. Res., 113, G01021, doi:10.1029/ 2007JG000563.

, and Coauthors, 2010: Technical description of version 4.0 of the Community Land Model (CLM). NCAR Tech. Note NCAR/TN-478+STR, 257 pp. [Available online at http:// nldr.library.ucar.edu/repository/collections/TECH-NOTE000-000-000-848.]

Pavlov, A. V., and N. G. Moskalenko, 2002: The thermal regime of soils in the north of western Siberia. Permafrost Periglacial Processes, 13, 43-51.

Peacock, S., 2012: Projected twenty-first-century changes in temperature, precipitation, and snow cover over North America in CCSM4. J. Climate, 25, 4405-4429.

Qian, T. T., A. G. Dai, K. E. Trenberth, and K. W. Oleson, 2006: Simulation of global land surface conditions from 1948 to 2004. Part I: Forcing data and evaluations. J. Hydrometeor., 7, 953-975.

Riahi, K., and Coauthors, 2011: RCP 8.5-A scenario of comparatively high greenhouse gas emissions. Climatic Change, 109, 33-57.

Ringeval, B., P. Friedlingstein, C. Koven, P. Ciais, N. de NobletDucoudre, B. Decharme, and P. Cadule, 2011: Climate- $\mathrm{CH}_{4}$ feedback from wetlands and its interaction with the climate$\mathrm{CO}_{2}$ feedback. Biogeosciences, 8, 2137-2157.

Riseborough, D., N. Shiklomanov, B. Etzelmuller, S. Gruber, and S. Marchenko, 2008: Recent advances in permafrost modelling. Permafrost Periglacial Processes, 19, 137-156.

Saito, K., 2008: Arctic land hydrothermal sensitivity under warming: Idealized off-line evaluation of a physical terrestrial scheme in a global climate model. J. Geophys. Res., 113, D21106, doi:10.1029/2008JD009880.

Schaefer, K., T. J. Zhang, L. Bruhwiler, and A. P. Barrett, 2011: Amount and timing of permafrost carbon release in response to climate warming. Tellus, 63B, $165-180$.

Schuur, E. A. G., and B. Abbott, 2011: Climate change: High risk of permafrost thaw. Nature, 480, 32-33.

— , and Coauthors, 2008: Vulnerability of permafrost carbon to climate change: Implications for the global carbon cycle. BioScience, 58, 701-714.

Sellers, P. J., and Coauthors, 1996a: A revised land surface parameterization (SiB2) for atmospheric GCMs. 1. Model formulation. J. Climate, 9, 676-705. 
and Coauthors, 1996b: Comparison of radiative and physiological effects of doubled atmospheric $\mathrm{CO}_{2}$ on climate. Science, 271, 1402-1406.

Shiklomanov, N. I., O. A. Anisimov, T. Zhang, S. Marchenko, F. E. Nelson, and C. Oelke, 2007: Comparison of model-produced active layer fields: Results for northern Alaska. J. Geophys. Res., 112, F02S10, doi:10.1029/2006JF000571.

Smith, L., Y. Sheng, G. MacDonald, and L. Hinzman, 2005: Disappearing arctic lakes. Science, 308, 1429-1429.

Stieglitz, M., S. J. Dery, V. E. Romanovsky, and T. E. Osterkamp, 2003: The role of snow cover in the warming of arctic permafrost. Geophys. Res. Lett., 30, 1721, doi:10.1029/ 2003 GL017337.

Swenson, S. C., D. M. Lawrence, and H. Lee, 2012: Improved simulation of the terrestrial hydrological cycle in permafrost regions by the Community Land Model. J. Adv. Model. Earth Syst., 4, M08002, doi:10.1029/2012MS000165.

Tarnocai, C., J. G. Canadell, E. A. G. Schuur, P. Kuhry, G. Mazhitova, and S. Zimov, 2009: Soil organic carbon pools in the northern circumpolar permafrost region. Global Biogeochem. Cycles, 23, GB2023, doi:10.1029/2008GB003327.

van Groenigen, K. J., C. W. Osenberg, and B. A. Hungate, 2011: Increased soil emissions of potent greenhouse gases under increased atmospheric $\mathrm{CO}_{2}$. Nature, 475, 214-216.
Vavrus, S. J., M. M. Holland, A. Jahn, D. A. Bailey, and B. A. Blazey, 2011: Twenty-first-century Arctic climate change in CCSM4. J. Climate, 25, 2696-2710.

Westermann, S., J. Boike, M. Langer, T. V. Schuler, and B. Etzelmuller, 2011: Modeling the impact of wintertime rain events on the thermal regime of permafrost. Cryosphere, 5, 945-959.

Zhang, T., 2005: Influence of the seasonal snow cover on the ground thermal regime: An overview. Rev. Geophys., 43, RG4002, doi:10.1029/2004RG000157.

— , and K. Stamnes, 1998: Impact of climatic factors on the active layer and permafrost at Barrow, Alaska. Permafrost Periglacial Processes, 9, 229-246.

_ R. G. Barry, D. Gilichinsky, S. S. Bykhovets, V. A. Sorokovikov, and J. P. Ye, 2001: An amplified signal of climatic change in soil temperatures during the last century at Irkutsk, Russia. Climatic Change, 49, 41-76.

Zhang, Y., W. J. Chen, S. L. Smith, D. W. Riseborough, and J. Cihlar, 2005: Soil temperature in Canada during the twentieth century: Complex responses to atmospheric climate change. J. Geophys. Res., 110, D03112, doi:10.1029/2004JD004910.

Zona, D., D. A. Lipson, K. T. Paw U, S. F. Oberbauer, P. Olivas, B. Gioli, and W. C. Oechel, 2012: Increased $\mathrm{CO}_{2}$ loss from vegetated drained lake tundra ecosystems due to flooding. Global Biogeochem. Cycles, 26, GB2004, doi:10.1029/2011GB004037. 